\title{
Nitrogen oxides and PAN in plumes from boreal fires during ARCTAS-B and their impact on ozone: an integrated analysis of aircraft and satellite observations
}

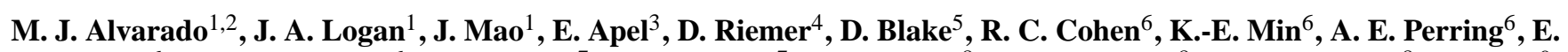 \\ C. Browne ${ }^{6}$, P. J. Wooldridge ${ }^{6}$, G. S. Diskin ${ }^{7}$, G. W. Sachse ${ }^{7}$, H. Fuelberg ${ }^{8}$, W. R. Sessions 8 , D. L. Harrigan ${ }^{8}$, G. Huey ${ }^{9}$, \\ J. Liao ${ }^{9}$, A. Case-Hanks ${ }^{9}$, J. L. Jimenez ${ }^{10}$, M. J. Cubison ${ }^{10}$, S. A. Vay ${ }^{7}$, A. J. Weinheimer ${ }^{3}$, D. J. Knapp ${ }^{3}$, D. D. \\ Montzka $^{3}$, F. M. Flocke ${ }^{3}$, I. B. Pollack ${ }^{3}$, P. O. Wennberg ${ }^{11}$, A. Kurten ${ }^{11}$, J. Crounse ${ }^{11}$, J. M. St. Clair ${ }^{11}$, A. Wisthaler ${ }^{12}$, \\ T. Mikoviny ${ }^{12}$, R. M. Yantosca ${ }^{1}$, C. C. Carouge ${ }^{1}$, and P. Le Sager ${ }^{1}$ \\ ${ }^{1}$ School of Engineering and Applied Science, Harvard University, Cambridge, Massachusetts, USA \\ ${ }^{2}$ Now at Atmospheric and Environmental Research, Inc., Lexington, Massachusetts, USA \\ ${ }^{3}$ Atmospheric Chemistry Division, National Center for Atmospheric Research, Boulder, Colorado, USA \\ ${ }^{4}$ Rosenstiel School of Marine and Atmospheric Science, University of Miami, Miami, Florida, USA \\ ${ }^{5}$ School of Physical Sciences, University of California, Irvine, California, USA \\ ${ }^{6}$ Chemistry Department, University of California, Berkeley, California, USA \\ ${ }^{7}$ NASA Langley Research Center, Hampton, Virginia, USA \\ ${ }^{8}$ Department of Meteorology, Florida State University, Tallahassee, Florida, USA \\ ${ }^{9}$ School of Earth and Atmospheric Sciences, Georgia Institute of Technology, Atlanta, Georgia, USA. \\ ${ }^{10}$ Department of Chemistry and Cooperative Institute for Research in the Environmental Sciences, University of Colorado, \\ Boulder, Colorado, USA \\ ${ }^{11}$ California Institute of Technology, Pasadena, California, USA \\ ${ }^{12}$ Institut für Ionenphysik \& Angewandte Physik, University of Innsbruck, Innsbruck, Austria
}

Received: 8 June 2010 - Published in Atmos. Chem. Phys. Discuss.: 22 June 2010

Revised: 7 October 2010 - Accepted: 8 October 2010 - Published: 18 October 2010

\begin{abstract}
We determine enhancement ratios for $\mathrm{NO}_{\mathrm{x}}, \mathrm{PAN}$, and other $\mathrm{NO}_{\mathrm{y}}$ species from boreal biomass burning using aircraft data obtained during the ARCTAS-B campaign and examine the impact of these emissions on tropospheric ozone in the Arctic. We find an initial emission factor for $\mathrm{NO}_{\mathrm{x}}$ of $1.06 \mathrm{~g} \mathrm{NO}$ per kg dry matter (DM) burned, much lower than previous observations of boreal plumes, and also one third the value recommended for extratropical fires. Our analysis provides the first observational confirmation of rapid PAN formation in a boreal smoke plume, with $40 \%$ of the initial $\mathrm{NO}_{\mathrm{x}}$ emissions being converted to PAN in the first few hours after emission. We find little clear evidence for ozone formation in the boreal smoke plumes during ARCTAS-B in either aircraft or satellite observations, or in model simulations. Only a third of the smoke plumes observed by the NASA
\end{abstract}

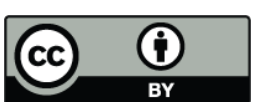

Correspondence to: M. J. Alvarado (matthew.alvarado@aer.com)
DC8 showed a correlation between ozone and CO, and ozone was depleted in the plumes as often as it was enhanced. Special observations from the Tropospheric Emission Spectrometer (TES) also show little evidence for enhanced ozone in boreal smoke plumes between 15 June and 15 July 2008. Of the 22 plumes observed by TES, only 4 showed ozone increasing within the smoke plumes, and even in those cases it was unclear that the increase was caused by fire emissions. Using the GEOS-Chem atmospheric chemistry model, we show that boreal fires during ARCTAS-B had little impact on the median ozone profile measured over Canada, and had little impact on ozone within the smoke plumes observed by TES.

\section{Introduction}

Emissions of $\mathrm{NO}_{\mathrm{x}}\left(\mathrm{NO}+\mathrm{NO}_{2}\right)$ and other $\mathrm{NO}_{\mathrm{y}}$ species from boreal fires can influence the formation of ozone in the Arctic and midlatitudes (e.g., Wofsy et al., 1992; Jacob et al., 1992;

Published by Copernicus Publications on behalf of the European Geosciences Union. 
Table 1. Previous measurements of $\mathrm{NO}_{\mathrm{x}}$ and $\mathrm{NO}_{\mathrm{y}}$ enhancement ratios (mol/mol) for boreal plumes.

\begin{tabular}{lcccl}
\hline Source & Study Type & Location & Age (h) & Enhancement Ratio \\
\hline Nance et al. (1993) & Aircraft & Alaska & $<1$ & $\Delta \mathrm{NO}_{\mathrm{x}} / \Delta \mathrm{CO}=1.2 \%$ \\
Goode et al. (2000) & Aircraft & Alaska & $<1$ & $\Delta \mathrm{NO} / \Delta \mathrm{CO}=1.4 \%-1.8 \%$ \\
Wofsy et al. (1992) & Aircraft & Alaska, Canada & $24-48$ & $\Delta \mathrm{NO}_{\mathrm{y}} / \Delta \mathrm{CO}=0.56 \%$ \\
Val Martin et al. (2006) & Surface & Azores & $150-360$ & $\Delta \mathrm{NO}_{\mathrm{y}} / \Delta \mathrm{CO}=0.8 \%$ \\
McKeen et al. (2002) & Model & SE US & 50 & $\Delta \mathrm{NO}_{\mathrm{y}} / \Delta \mathrm{CO} \geq 0.7 \%$ \\
\hline
\end{tabular}

Table 2. Previous measurements of $\mathrm{O}_{3}$ enhancement ratios ( $\mathrm{mol} / \mathrm{mol}$ ) for boreal plumes.

\begin{tabular}{|c|c|c|c|c|c|}
\hline Source & Study Type & Location & Age (h) & N. Corr. & $\Delta \mathrm{O}_{3} / \Delta \mathrm{CO}$ \\
\hline Goode et al. (2000) & Aircraft & Alaska & $0-3$ & 1 & $7.9 \% \pm 2.4 \%$ \\
\hline Wofsy et al. (1992) & Aircraft & Alaska & $24-48$ & 1 of 3 & $17.5 \%^{a}$ \\
\hline Mauzerall et al. (1996) & Aircraft & E. Canada & Aged & 4 of 9 & $10 \% \pm 20 \%$ \\
\hline Wotawa and Trainer (2000) & Surface, Aircraft & SE US & 50 & 1 & $11 \%$ \\
\hline Honrath et al. (2004) & Surface & Azores & $300-360$ & 4 & $40 \%-90 \%$ \\
\hline Val Martin et al. (2006) & Surface & Azores & $150-360$ & 9 & $20 \%(-40 \%-90 \%)$ \\
\hline Pfister et al. (2006) & Surface & Azores & $150-360$ & - & $23 \%-28 \%$ \\
\hline \multirow[t]{3}{*}{ Real et al. (2007) } & Aircraft & E. Canada & & 1 & \\
\hline & & Azores & 120 & & $-1 \%^{b}$ \\
\hline & & France & 240 & & $8 \%^{b}$ \\
\hline Bertschi and Jaffe (2005) & Aircraft & Washington State & $170-240$ & 5 & $44 \% \pm 30 \%$ \\
\hline Verma et al. (2009) & TES & Siberia & $0-120$ & 32 & $0 \%$ (mean) \\
\hline
\end{tabular}

a Value for the single correlated plume.

b Values are for the same smoke parcel measured at different distances downwind.

Mauzerall et al., 1996; Wotawa and Trainer, 2000; Val Martin et al., 2006; Real et al., 2007; Leung et al., 2007). Quantitative estimates of these emissions are essential to determining the impact of these fires on tropospheric ozone. However, current $\mathrm{NO}_{\mathrm{x}}$ emission factors for boreal fires are based on only two studies of $\mathrm{NO}_{\mathrm{x}}$ in fresh boreal smoke (Nance et al., 1993; Goode et al., 2000), two studies of $\mathrm{NO}_{\mathrm{y}}$ in aged boreal smoke (Wofsy et al., 1992; Val Martin et al., 2006), and one model study (McKeen et al., 2002), as shown in Table 1 . Furthermore, oxidation within the plume can rapidly convert $\mathrm{NO}_{\mathrm{x}}$ to other $\mathrm{NO}_{\mathrm{y}}$ species, such as $\mathrm{HNO}_{3(\mathrm{~g})}$, peroxynitrates (PNs) $\left(\mathrm{RO}_{2} \mathrm{NO}_{2}\right.$, including peroxyacetyl nitrate (PAN)), alkyl nitrates (ANs) $\left(\mathrm{RONO}_{2}\right)$ and aerosol nitrate, reducing ozone formation in the plume, with transport of PAN potentially increasing the influence of boreal forest fires on ozone formation downwind (Jacob et al., 1992; Leung et al., 2007).

Some previous modeling studies have found that estimates of the emissions of $\mathrm{NO}_{\mathrm{x}}$ from boreal fires based on the above studies lead to too much $\mathrm{NO}_{\mathrm{x}}$ and ozone in modeled fire plumes when compared with aircraft and satellite observations. For example, Cook et al. (2007) used p-TOMCAT to model ozone production in forest fire plumes from Canada and Alaska encountered during the International Consortium for Atmospheric Research on Transport and Transformation
(ICARTT) campaign in the summer of 2004. The model initially overestimated $\mathrm{NO}_{\mathrm{x}}$ and ozone in the smoke plumes. However, reducing the $\mathrm{NO}_{2}$ emission ratio from $3.3 \%$ to $0.8 \%$ and increasing the vertical mixing of ozone above the fires reduced model ozone closer to the aircraft observations and model $\mathrm{NO}_{2}$ closer to the SCIAMACHY data. Hudman et al. (2007) also found that the estimates of biomass burning $\mathrm{NO}_{\mathrm{x}}$ emissions based on the inventory described by Turquety et al. (2007) with a $\mathrm{NO}_{\mathrm{x}}$ emission ratio of $3.3 \%$ had to be modified to match the ICARRT observations of $\mathrm{NO}_{\mathrm{x}}$ and PAN by releasing $80 \%$ of the $\mathrm{NO}_{\mathrm{x}}$ as PAN.

The observed formation of ozone within boreal biomass burning plumes varies greatly between studies. Enhanced ozone has been found in some, but not all, aged boreal smoke plumes, as shown in Table 2. Goode et al. (2000) sampled a single fresh Alaskan smoke plume and found an enhancement of ozone within the smoke plume of $7.9 \% \pm 2.4 \%$ three hours after emission. Wofsy et al. (1992) and Mauzerall et al. (1996) found mixed results: only a third of the aged plumes sampled showed a significant correlation between ozone and CO, with Mauzerall et al. (1996) finding an average enhancement ratio of $10 \% \pm 20 \%$. Observations of highly aged boreal smoke plumes over the Azores, 6-15 days downwind of the fires, have shown a wide variation in ozone enhancement $(-40 \%-90 \%)$ with an average around $20 \%$ (Honrath et al., 
2004; Val Martin et al., 2006; Pfister et al., 2006). However, the study of smoke plumes over Siberia in 2006 by Verma et al. (2009) using the Tropospheric Emission Spectrometer (TES) aboard the Aura satellite found that while some smoke plumes were enhanced in ozone, others were depleted. They found that the average ozone in the smoke plumes was not significantly different from that in the background atmosphere.

The summer Arctic Research of the Composition of the Troposphere from Aircraft and Satellites (ARCTAS-B) campaign in late June and early July 2008 (Jacob et al., 2009) provided an unprecedented opportunity to sample many fresh and aged boreal smoke plumes using the NASA DC 8 aircraft and to make detailed measurements of ozone and $\mathrm{NO}_{\mathrm{y}}$ species. The observations of the Lake McKay plume sampled by the DC8 on 1 July also provide direct observations of the rapid transformation of $\mathrm{NO}_{\mathrm{x}}$ into other $\mathrm{NO}_{\mathrm{y}}$ species shortly after emission. We use these observations to study the rapid transformation of $\mathrm{NO}_{\mathrm{x}}$ into PAN in the first few hours after emission, to determine the enhancement ratios of $\mathrm{NO}_{\mathrm{x}}$, PAN, and other nitrates in fresh ( $\leq 1$ day old) Canadian boreal smoke plumes and to develop better estimates of emission factors for these species for use in models, and to quantify the observed enhancement of ozone within these boreal fire plumes.

The TES instrument made multiple special observations during the summer of 2008 over eastern Siberia, the North Pacific and North America, providing several retrievals of $\mathrm{CO}$ and ozone within fresh and aged boreal biomass burning plumes. These data allow us to put the aircraft observations into a much larger context. Here we use the TES special observations to examine the relationship between $\mathrm{CO}$ and ozone in boreal smoke plumes between 15 June and 15 July 2008 .

Finally, we use the GEOS-Chem model (Bey et al., 2001) to quantify the effect of the new emission factors for $\mathrm{NO}_{\mathrm{x}}$, PAN, and inorganic nitrate from boreal fires on ozone formation. We perform three simulations: one using the default emissions for extratropical fires described below; a second using updated emissions derived from the NASA DC8 data; and a third hypothetical case where there are no extratropical fire emissions. We then evaluate the model simulations using the aircraft and satellite observations and use the model to explore the sensitivity of ozone to boreal fire emissions.

Section 2 describes the identification of smoke plumes sampled by the DC8 during ARCTAS-B, the determination of the enhancement ratios of $\mathrm{NO}_{\mathrm{y}}$ species and ozone in the plumes, the TES special observations used in this study, and the GEOS-Chem model runs performed. Section 3 compares our estimates of the emission ratios of $\mathrm{NO}_{\mathrm{y}}$ species and of the downwind enhancement of ozone in these plumes to previous studies, evaluates the model simulations using the aircraft and satellite observations, and shows the sensitivity of the model to extratropical biomass burning emissions.

\section{Methods}

\subsection{Analysis of ARCTAS-B DC8 observations}

\subsubsection{All plumes}

We examined the NASA DC8 data sets between 29 June and 10 July 2008 for evidence of biomass burning plumes. The species discussed here, and the techniques used to measure them, are described in Table 3. A plume was assumed to be from biomass burning when the one minute average $\mathrm{CO}$ concentration rose at least $20 \mathrm{ppb}$ above the background level and the enhancement of $\mathrm{CO}$ was correlated (defined throughout as when $r^{2}>0.3$ ) with an enhancement in $\mathrm{HCN}$ (using $1 \mathrm{~s}$ average data) and/or $\mathrm{CH}_{3} \mathrm{CN}$ (using $20 \mathrm{~s}$ average data). Back trajectories were used to eliminate aged plumes from California fires and those potentially mixed with Asian anthropogenic pollution (Fuelberg et al., 2010). Enhancement ratios of various species versus $\mathrm{CO}$ in the plumes were determined from the slope of the reduced major axis linear regression between the two species in the merged data (Isobe et al., 1990). The averaging time for the data merge used in the linear regression varied depending on the averaging time and frequency of the measurement technique used for the non$\mathrm{CO}$ species; the $\mathrm{CO}$ observations had a native time resolution of $1 \mathrm{~s}$. The averaging times of the data merges used for each species are shown in Table 3. The relative age of the plumes was classified based on the correlation of $\mathrm{CO}$ with shortlived organic species of varying lifetimes following Mauzerall et al. (1998). The mean observed daytime $\mathrm{OH}$ concentration during ARCTAS-B varied between $1-2.5 \times 10^{6} \mathrm{~cm}^{-3}$; while we do not compare modeled and observed $\mathrm{OH}$ in this paper, Mao et al. (2010) used data from ARCTAS-A in the spring of 2008 to show that GEOS-Chem OH concentrations were within $15 \%$ of the observations between $1-6 \mathrm{~km}$, with a $40 \%$ underestimate below $1 \mathrm{~km}$ and a $40 \%$ overestimate above $6 \mathrm{~km}$. Plumes where the $\mathrm{CO}$ was correlated with propene (lifetime of $4-10 \mathrm{~h}$ for the mean observed daytime $\mathrm{OH}$ concentration) were classified as "fresh". Plumes where CO was correlated with ethene (14-35 h) or toluene (19-46 h) but not propene were classified as "aged", while plumes where $\mathrm{CO}$ was correlated with butane $(47-117 \mathrm{~h})$, benzene (87-217 h), or propane (101-252 h) were classified as "old".

\subsubsection{Lake McKay fire plume}

For the Lake McKay fire $\left(56.5^{\circ} \mathrm{N}, 106.8^{\circ} \mathrm{W}\right)$ on $1 \mathrm{July}$, the DC8 sampled the fresh smoke plume at several distances downwind from the fire source at the beginning (early pass, 13:00-15:00 LT) and end (late pass, 18:20-19:40 LT) of the flight. Enhancement ratios of $\mathrm{NO}_{\mathrm{x}}, \mathrm{NO}_{\mathrm{y}}$, and ozone for each plume crossing were determined using reduced major axis linear regressions of the one second merged data, the same as was done for all DC8 plumes above. For PAN, which was measured by chemical ionization mass spectrometry (CIMS) 
Table 3. DC-8 measurements used in this analysis

\begin{tabular}{|c|c|c|c|c|}
\hline Species $^{\mathrm{a}}$ & Method $^{\mathrm{b}}$ & Principal Investigator & Ref. & $\begin{array}{l}\text { Avg. Time for } \\
\text { Regression with CO }\end{array}$ \\
\hline $\mathrm{CO}$ & TDLAS & G. Diskin & $\begin{array}{l}\text { Sachse et al. (1987), } \\
\text { Diskin et al. (2002) }\end{array}$ & NA \\
\hline $\mathrm{O}_{3}, \mathrm{NO}, \mathrm{NO}_{2}, \mathrm{NO}_{\mathrm{y}}$ & Chemiluminescence & A. Weinheimer & Weinheimer et al. (1994) & $1 \mathrm{~s}$ \\
\hline $\mathrm{CO}_{2}$ & Non-dispersive IR & S. Vay & Vay et al. (2003) & $1 \mathrm{~s}$ \\
\hline PAN & CIMS & G. Huey & $\begin{array}{l}\text { Slusher et al. (2004), } \\
\text { Kim et al. (2007) }\end{array}$ & $30 \mathrm{~s}$ \\
\hline Total PNs, Total ANs & TD-LIF & R. Cohen & Day et al. (2002) & $60 \mathrm{~s}^{\mathrm{c}}$ \\
\hline Fine Aerosol $\mathrm{NO}_{3(\mathrm{p})}$ & HR-ToF-AMS & J. L. Jimenez & DeCarlo et al. (2008) & $10 \mathrm{~s}$ \\
\hline $\mathrm{HCN}, \mathrm{HNO}_{3(\mathrm{~g})}$ & CIMS & P. Wennberg & Crounse et al. $(2006,2009)$ & $1 \mathrm{~s}$ \\
\hline NMHCs & WAS-GC & D. Blake & Blake et al. (2003) & Variable $^{\mathrm{d}}$ \\
\hline Organic gases, $\mathrm{CH}_{3} \mathrm{CN}$ & PTR-MS & A. Wisthaler & Wisthaler et al. (2002) & $20 \mathrm{~s}^{\mathrm{e}}$ \\
\hline NMHCs, OVOCs & GC-MS & $\begin{array}{l}\text { E. Apel and } \\
\text { D. Riemer }\end{array}$ & Apel et al. (2003) & Variable $^{\mathrm{d}}$ \\
\hline
\end{tabular}

${ }^{\text {a }}$ NMHCs = nonmethane hydrocarbons OVOCs = oxygenated volatile organic compounds

$\mathrm{b}$ TDLAS = Tunable Diode Laser Absorption Spectroscopy; CIMS = Chemical Ionization Mass Spectrometry;

TD-LIF = Thermal-Dissociation Laser Induced Fluorescence;

HR-ToF-AMS = High-Resolution Time-of-Flight Aerosol Mass Spectrometer; WAS-GC = Whole Air Sampling - Gas Chromatography;

PTR-MS = Proton Transfer Reaction - Mass Spectrometry; GC-MS = Gas Chromatography-Mass Spectrometry

${ }^{\mathrm{c}}$ Reported averaging time of $\mathrm{PN}$ and AN measurements by TD-LIF are $\sim 10 \mathrm{~s}$, with variable time between measurements.

d NASA LaRC provided CO data averaged to match WAS-GC and GC-MS averaging times.

e PTR-MS measurements have a reported averaging time of $0.5 \mathrm{~s}$, with 10 to $20 \mathrm{~s}$ between measurements.

and had an archived measurement frequency and averaging time of $30 \mathrm{~s}$, there were too few data points in each short plume crossing to determine the enhancement from a linear regression. Instead, the PAN enhancement ratios for each plume crossing were determined by calculating the average PAN and CO mixing ratios for the plume crossing and assuming background concentrations equal to the 25 th percentile of all measurements on 1 July between 0 and $2 \mathrm{~km}$ in altitude; $140 \mathrm{ppb}$ for CO and $180 \mathrm{ppt}$ for PAN. Modified combustion efficiencies were calculated using a $\mathrm{CO}_{2}$ background concentration of $382 \mathrm{ppm}$ and average $\mathrm{CO}_{2}$ mixing ratios for the plume crossing.

\subsection{TES observations during ARCTAS-B}

We used the Level 2 retrievals of $\mathrm{CO}$ and ozone from TES (V003, Osterman et al. (2008)) to further explore ozone enhancement in boreal smoke plumes. TES V003 ozone retrievals were validated against ozonesonde profiles from the Arctic Intensive Ozonesonde Network Study (ARCIONS) during ARCTAS (April to July 2008, Boxe et al. (2009)), and generally showed a positive mean bias of less than $15 \%$. The TES special observations include nadir retrievals at about every $0.4^{\circ}$ latitude, a much closer spacing than the global survey observations $\left(1.6^{\circ}\right.$ apart), which allows us to look at changes in ozone levels in biomass burning plumes. The retrievals were filtered for data quality as recommended in the TES Level 2 Data Users Guide (Osterman et al., 2008). We used maps of Level 3 daily AIRS retrievals of $\mathrm{CO}$ at

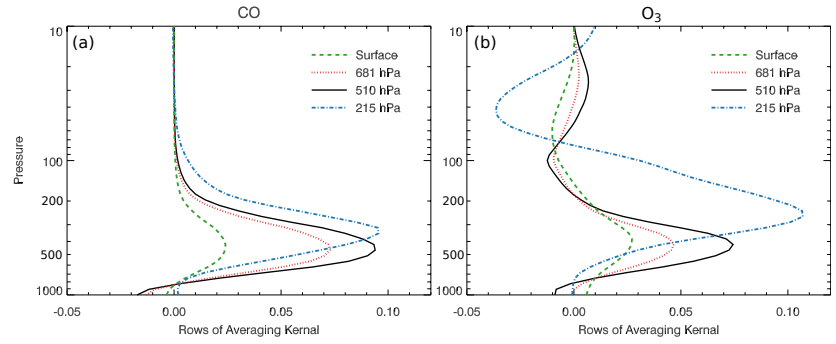

Fig. 1. Averaging kernels of (a) $\mathrm{CO}$ and (b) ozone at four different pressure levels. Data is from TES run 7706 on 3 July 2008 at $44.5^{\circ} \mathrm{N}, 158.3^{\circ} \mathrm{W}$.

$1^{\circ} \times 1^{\circ}$ resolution (available at http://disc.sci.gsfc.nasa.gov/ giovanni/ $\backslash \#$ maincontent) to identify the transport of emissions from major regions of boreal biomass burning and then identified the plumes that were observed by TES. Here, we defined a plume as a set of TES retrievals between 15 June and 15 July where peak $\mathrm{CO}$ exceeded $150 \mathrm{ppb}$ at $510 \mathrm{hPa}$ and where HYSPLIT back-trajectories (http://ready.arl.noaa.gov/ HYSPLIT.php) suggested the observed air masses came from boreal biomass burning regions in Siberia (17 plumes) and Canada (5 plumes).

Figure 1 shows the $\mathrm{CO}$ and ozone averaging kernels for TES Run 7706 on 3 July 2008 at the location of a plume encounter $\left(44.5^{\circ} \mathrm{N}, 158.3^{\circ} \mathrm{W}\right)$ at four different pressure levels. In general, the retrievals had 1 degree of freedom for signal 


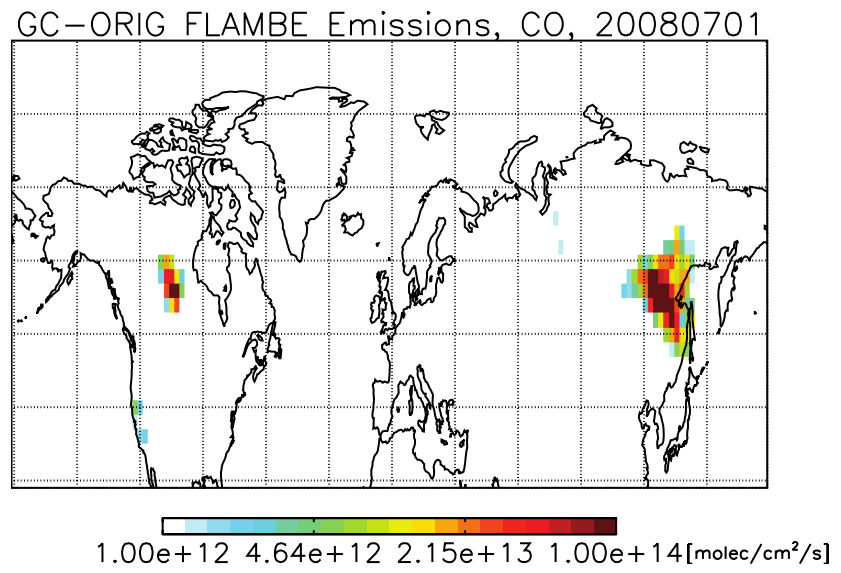

Fig. 2. Emissions of CO from extratropical fires on 1 July 2008 for the GC-ORIG model run. Estimates of the amount of biomass burned are from the FLAMBE database, while the emission factor for CO is from Andreae and Merlet (2001).

(DOFS) below $250 \mathrm{hPa}$ for both ozone and CO. The criteria of $150 \mathrm{ppb}$ for $\mathrm{CO}$ ensures that the retrievals are significantly different from the a priori values $(\sim 110 \mathrm{ppb})$. While this procedure will detect thick plumes that are transported between continents (e.g., Zhang et al., 2008), it will not detect plumes near the surface (where the sensitivity is low) or very thin and highly diluted plumes. Of the 27 plumes encountered by the DC8 during ascents and descents, the median thickness was $1.5 \mathrm{~km}$; eight had a thickness less than $1 \mathrm{~km}$, and 2 had a thickness of less than $0.5 \mathrm{~km}$.

\subsection{GEOS-chem modeling and sensitivity study}

We performed a simulation for the ARCTAS-B period (15 June to 15 July 2008) using the GEOS-Chem model and evaluated the simulation with the DC8 and TES observations. The model is described in detail in Mao et al. (2010), while model emissions are documented in Fisher et al. (2010).

GEOS-Chem (Bey et al., 2001) is a global 3-D chemical transport model driven by assimilated meteorological observations from the Goddard Earth Observing System (GEOS5) of the NASA Global Modeling and Assimilation Office (GMAO) (Rienecker et al., 2007). We use GEOS-Chem version 8-01-04 (http://acmg.seas.harvard.edu/geos/index.html) with a dynamic time step of $15 \mathrm{~min}$ and a chemistry time step of $60 \mathrm{~min}$. The GEOS-5 meteorological data have 6-h resolution (3-h for surface variables and mixing depths) and are regridded for input to GEOS-Chem. The model is initialized with a 1-year simulation from January 2007 to January 2008 with $4^{\circ} \times 5^{\circ}$ resolution, and from January 2008 on with $2^{\circ} \times 2.5^{\circ}$ resolution. The same GEOS-Chem simulation was used to interpret ARCTAS-A observations for $\mathrm{HO}_{\mathrm{x}}$ (Mao et al., 2010) and CO (Fisher et al., 2010).
We use the standard GEOS-Chem simulation of ozone$\mathrm{NO}_{\mathrm{x}}-\mathrm{HO}_{\mathrm{x}}-\mathrm{VOC}$-aerosol chemistry as described for example by Park et al. (2006). The chemical mechanism is updated with data from Sander et al. (2006) (hereinafter "JPL06") and the International Union of Pure and Applied Chemistry (Atkinson et al., 2006). The Fast-JX method was used to calculate photolysis rates (Wild et al., 2000; Bian and Prather, 2002), and the absorption cross-sections and quantum yields were updated following JPL06. Total ozone columns used as input to Fast-JX are from daily measurements by the Ozone Monitoring Instrument (OMI) satellite instrument with $1^{\circ} \times 1^{\circ}$ resolution (ftp://toms.gsfc.nasa.gov/ pub/omi/data/ozone/Y2008/). Surface albedo is from the Total Ozone Mapping Spectrometer (TOMS) satellite monthly climatology with $1^{\circ} \times 1.25^{\circ}$ resolution (Herman and Celarier, 1997).

Anthropogenic emissions in GEOS-Chem are described in van Donkelaar et al. (2008). Daily total carbon emissions from biomass burning for 2008 with $1^{\circ} \times 1^{\circ}$ resolution are specified from the Fire Locating and Monitoring of Burning Emissions (FLAMBE) emission inventory (Reid et al., 2009) constrained by GOES and MODIS fire count data. Monthly mean biomass burning emissions from the Global Fire Emissions Database v.2 (GFEDv2) inventory for 2007 were used for the 1 year model spin up (Giglio et al., 2006; van der Werf et al., 2006). Emissions of specific gases were calculated from the total carbon emissions using the emission factors of Andreae and Merlet (2001). Emissions from biomass burning were uniformly distributed throughout the boundary layer, with boundary layer heights taken from GEOS-5 meteorology. This could underestimate the amount of fresh smoke injected into the free troposphere: previous work using MISR derived plume heights suggests that $4-12 \%$ of North American fire plumes are injected above the boundary layer at the time of the MISR overpass (between 11:10 and 13:45 local time) (Val Martin et al., 2010). Figure 2 shows the emissions of CO for the base model run, GC-ORIG, on 1 July 2008. The emissions were strongest from the Siberian fires on this day, with relatively smaller emissions over Canada and parts of California. Further details on model emissions are given by Fisher et al. (2010).

The median CO observations of the NASA DC8 in the lower troposphere (see Sect. 3.3.1) imply that the FLAMBE inventory overestimates the $\mathrm{CO}$ emissions, and hence the amount of biomass consumed by boreal fires during the study period. Aircraft data from ARCTAS-A also showed that the FLAMBE emissions of CO had to be reduced (to 53\% and $45 \%$ of the initial estimate for Russia and Southeast Asia, respectively) while the anthropogenic emissions had to be increased (by $18 \%$ and $52 \%$ for Asia and Europe, respectively) in the spring of 2008 (Fisher et al., 2010). Furthermore, we show in Sects. 3.1 and 3.2 that the emission factors in our base run, GC-ORIG, overestimate the emission ratio of $\mathrm{NO}_{\mathrm{y}}$ to $\mathrm{CO}$ in the smoke plumes and that much of the $\mathrm{NO}_{\mathrm{x}}$ initially emitted by the fires is rapidly converted to PAN and 

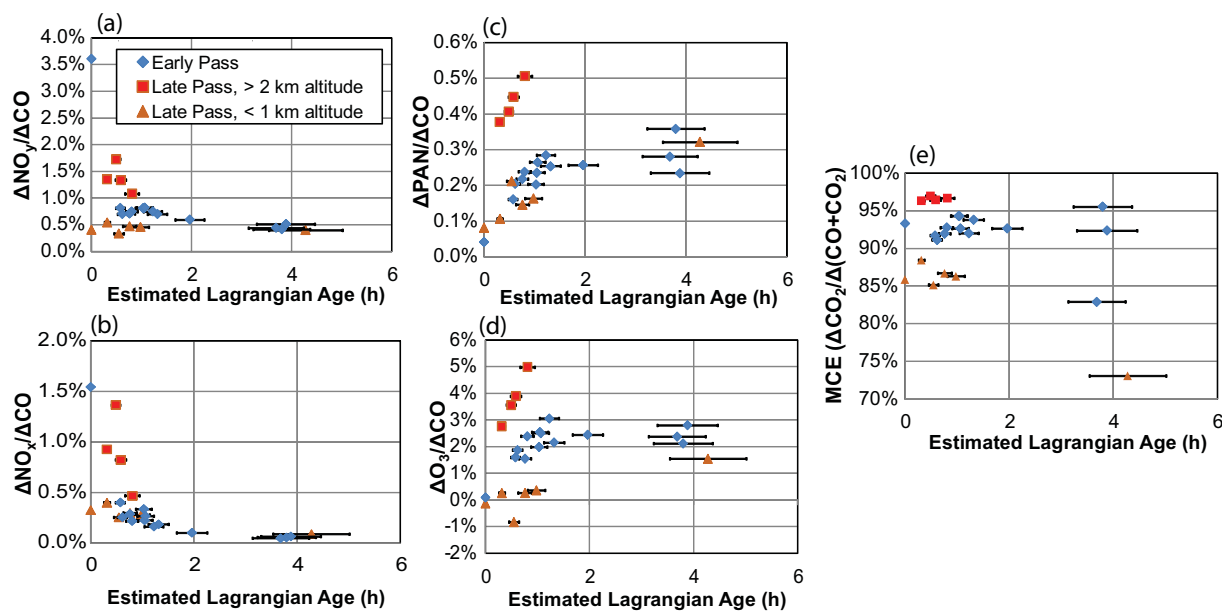

Fig. 3. Enhancement ratios of (a) $\mathrm{NO}_{y}$, (b) $\mathrm{NO}_{x}$, (c) PAN, and (d) $\mathrm{O}_{3}$ and (e) modified combustion efficiency (MCE) versus Lagrangian age for the Lake McKay smoke plume sampled during the 1 July flight of the DC8. Blue diamonds are for samples taken during the early pass (13:00-15:00 LT), while red squares and orange triangles are for samples taken during the late pass (18:20-19:40 LT) above $2 \mathrm{~km}$ and below $1 \mathrm{~km}$ in altitude, respectively.

inorganic nitrate $\left(\mathrm{HNO}_{3(\mathrm{~g})}\right.$ and $\left.\mathrm{NO}_{3(\mathrm{p})}\right)$ in the plume. Thus, we performed a sensitivity study (GC-SENS) to explore the effect of these changes to extratropical forest fire emission estimates and the subsequent sub-grid scale plume chemistry on the model results, as discussed in Sect. 3.3.1. The new emissions estimates in GC-SENS started on 15 June 2008. We also performed a second sensitivity study (GC-NOFIRE) with no emissions from extratropical forest fires as of 15 June 2008 to estimate the impacts of these fires on CO, ozone and $\mathrm{NO}_{\mathrm{y}}$ in the Arctic troposphere.

To compare the model results to the DC8 observations, the DC8 observations were averaged for 15 minutes to correspond to the dynamic time step of the model, and the model output was sampled along the flight track. The TES averaging kernel and a priori were applied to the model results along the TES orbit tracks to compare the model results with the TES retrievals as described by Zhang et al. (2006).

\section{Results and discussion}

\subsection{Rapid formation of PAN in the Lake McKay fire plumes}

The enhancement ratios of $\mathrm{NO}_{\mathrm{y}}, \mathrm{NO}_{\mathrm{x}}$, PAN (measured by CIMS), and $\mathrm{O}_{3}$ downwind of the Lake McKay fire are shown in Fig. 3. (Throughout this paper, emission and enhancement ratios (ERs) are reported as the molar ratio of a given species i to CO, expressed as a percent.) We estimated the Lagrangian age for each sample using the distance of each plume crossing from the location of maximum $\mathrm{CO}$ and the average measured wind speed $(8.5 \pm 1.3 \mathrm{~m} / \mathrm{s}$ for the early pass and $6.8 \pm 1.2 \mathrm{~m} / \mathrm{s}$ for the late pass). Uncertainty bars in Figs. 3-4 represent the $1 \sigma$ uncertainty in the Lagrangian age of the parcels based on the variability of the wind speed. The late pass data are divided into two sets, one for samples taken below $1 \mathrm{~km}$ and another for samples above $2 \mathrm{~km}$. These two sets show substantial differences in enhancement ratios and modified combustion efficiency $\left(\mathrm{MCE}=\Delta \mathrm{CO}_{2} / \Delta\left(\mathrm{CO}+\mathrm{CO}_{2}\right)\right)$, and so should be considered as two separate types of smoke parcels.

Total $\mathrm{NO}_{\mathrm{y}}$ enhancement ratios in Fig. 3a appear fairly constant in the lower late pass $(<1 \mathrm{~km}$ in altitude) with a range of $0.34 \%-0.55 \%$. The $\mathrm{NO}_{\mathrm{y}}$ enhancement ratio for the late pass samples at $2 \mathrm{~km}$ are much higher $(1.1 \%-1.7 \%)$. Most of this variability is due to the fluctuation between smoldering and flaming combustion in the Lake McKay fire, as evidenced by the variation of MCE shown in Fig. 3e. Pure smoldering combustion has an MCE of about $80 \%$, while pure flaming combustion has an MCE near 99\% (Yokelson et al., 1996). Thus the higher the MCE, the greater the proportion of flaming combustion to smoldering combustion, with values above $90 \%$ suggesting $\geq 50 \%$ flaming combustion (Sinha et al., 2003). Since CO is emitted mainly in smoldering combustion and $\mathrm{NO}_{\mathrm{x}}$ mainly in flaming combustion (Lobert et al., 1990), the higher $\mathrm{NO}_{\mathrm{x}}$ enhancement ratio in the upper late pass and the associated higher MCE imply that this sample is primarily from flaming combustion. For the early pass, the initial measurement of $\mathrm{NO}_{\mathrm{y}}$ enhancement ratio is very large, possibly as an artifact of the short plume transit time. This high value seems suspicious in light of the downwind observations, which show a much more gradual change from $0.8 \%$ to $0.4 \%$. This relatively constant behavior in the downwind $\mathrm{NO}_{\mathrm{y}}$ enhancement ratio is partially consistent with the MCE observations in the early pass: except for one downwind 
(a)

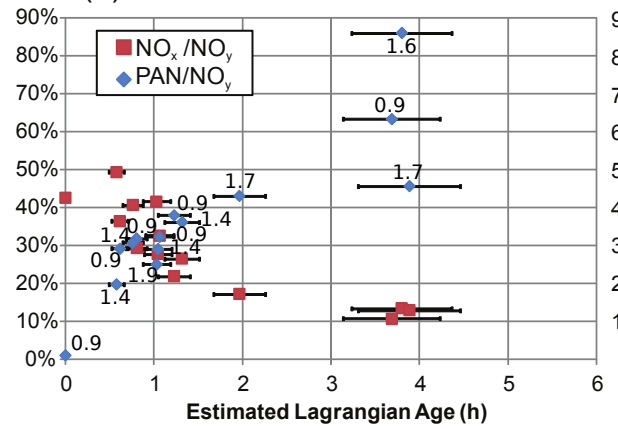

(b)

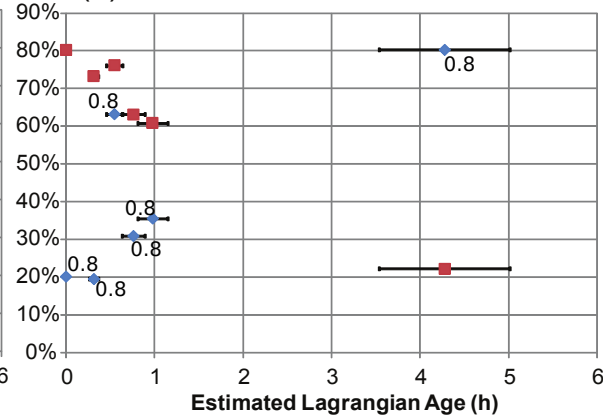

Fig. 4. Fraction of $\mathrm{NO}_{\mathrm{y}}$ present as $\mathrm{NO}_{\mathrm{x}}$ (orange squares) and PAN (blue diamonds) versus Lagrangian age for the (a) early pass (13:0015:00 LT) and (b) late pass (18:20-19:40 LT) of the Lake McKay fire plume. The late pass figure only includes samples taken below $1 \mathrm{~km}$ in altitude; altitude (in $\mathrm{km}$ ) is given in the text lebels attached to the blue diamonds.

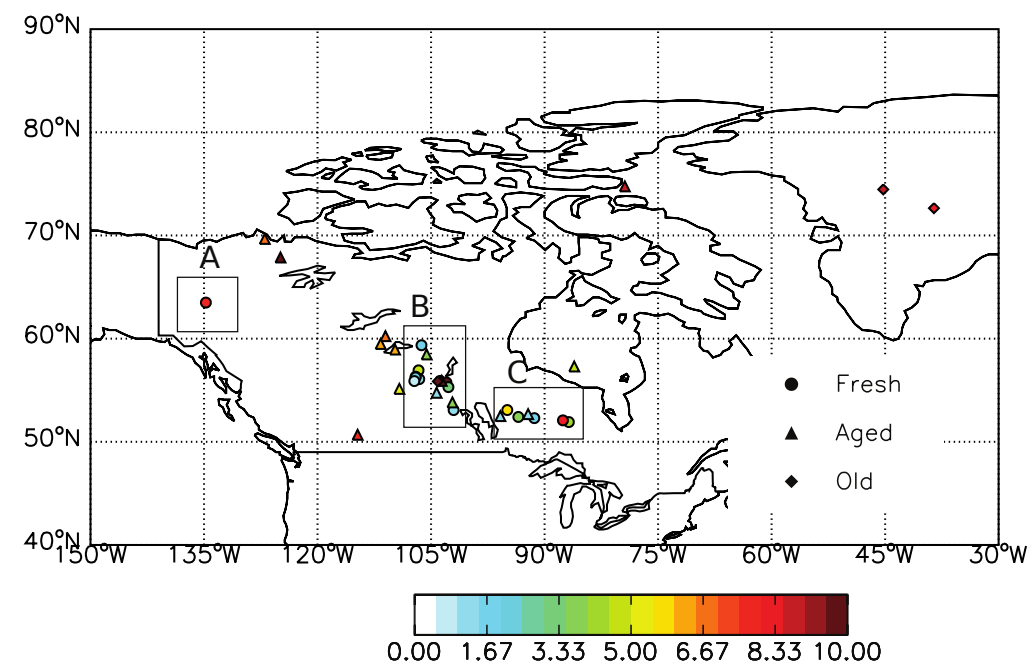

Fig. 5. Locations of smoke plumes encountered by the NASA DC8 during ARCTAS-B. The color represents the altitude of the plume while the symbol represents the age classification.

point at $83 \%$, the MCE in the early pass is fairly constant at $90 \%-96 \%$.

The $\mathrm{NO}_{\mathrm{x}}$ enhancement ratios, shown in Fig. 3b, decrease rapidly with age in both passes. Figure $3 \mathrm{c}$ shows that the PAN enhancement ratio increases rapidly in the early and lower late pass samples from initial values of $0.04 \%-0.08 \%$ to values of $0.23 \%-0.36 \%$ in $\sim 4$ hours after emission. Figure $3 \mathrm{~d}$ shows a rapid, if small, increase in the $\mathrm{O}_{3}$ enhancement ratio from small, and occasionally negative, initial values of $-0.8 \%-+0.1 \%$ (due to the titration of background $\mathrm{O}_{3}$ by fire-emitted NO), to positive downwind values of $2.1 \%-$ $2.8 \%$ in the early pass and $1.6 \%$ in the lower late pass. The upper late pass samples, with their higher $\mathrm{NO}_{\mathrm{y}}$ emission, showed much higher enhancements for PAN $(0.38 \%-$ $0.51 \%)$ and $\mathrm{O}_{3}(2.8 \%-5.0 \%)$. The measurements with large MCE values seem the most consistent with the previous measurements of $\mathrm{NO}_{\mathrm{x}}$ and $\mathrm{O}_{3}$ in fresh boreal smoke by Nance et al. (1993) and Goode et al. (2000). The results in Fig. 1 show that the $\mathrm{NO}_{\mathrm{x}}$ emission factor is strongly dependent on whether the combustion is flaming or smoldering, and that using previous measurements of fresh smoke that were likely from flaming combustion may overestimate the average $\mathrm{NO}_{\mathrm{x}}$ emissions from boreal fires.

Figure 4 shows that the $\mathrm{PAN} / \mathrm{NO}_{\mathrm{y}}$ ratio increases with age in both passes, while the $\mathrm{NO}_{\mathrm{x}} / \mathrm{NO}_{\mathrm{y}}$ ratio decreases. These observations of rapid PAN formation confirm the model result of Jacob et al. (1992), which showed PAN/NO in a boreal smoke plume increasing to about $30 \%$ in 3 hours. However, the model of Alvarado and Prinn (2009), which simulated the Alaskan fire plume sampled by Goode et al. (2000), showed a PAN/NO $/ \mathrm{Natio}_{\mathrm{y}}$ of only $4 \%$ after $3 \mathrm{~h}$. The key difference between the cases appears to be the emission ratio of $\mathrm{NO}_{\mathrm{x}}$ in the smoke plumes, which has a large effect on the modeled fractionation of $\mathrm{NO}_{\mathrm{y}}$ in the smoke plumes. In the 
case of Jacob et al. (1992), the initial value of $\Delta \mathrm{NO}_{\mathrm{x}} / \Delta \mathrm{CO}$ was $0.34 \%$, versus $4 \%$ in Alvarado and Prinn (2009) and $0.5 \%-1.5 \%$ for the early and late passes of the Lake McKay fire. We find that when the initial $\Delta \mathrm{NO}_{\mathrm{x}} / \Delta \mathrm{CO}$ values in the Alvarado and Prinn (2009) model are reduced to $0.5 \%-1.5 \%$, the $\mathrm{PAN} / \mathrm{NO}_{\mathrm{y}}$ ratio increases to $22 \%-31 \%$ after $3 \mathrm{~h}$.

\subsection{Characteristics of biomass burning plumes sampled by the NASA DC8}

\subsubsection{Plume age and height}

The locations of the plumes sampled by the DC8 are shown in Fig. 5, along with the altitude and age classification for each plume. The fresh plumes occurred in three regional groupings - a pyrocumulus cloud sampled on 29 June 2008 $\left(63.5^{\circ} \mathrm{N} 134.8^{\circ} \mathrm{W}\right.$, labeled $\mathrm{A}$ on the figure), a group of ten fresh plumes west of $97.5^{\circ} \mathrm{W}$ over the biomass burning source region (labeled B), and a third group of 5 fresh plumes east of $97.5^{\circ} \mathrm{W}$ downwind of the fire region (labeled C). The median altitude of all the fresh plumes was $2.7 \mathrm{~km}$. However, when only the plumes above the fire region are included, the median altitude drops to $1.6 \mathrm{~km}$, with 6 of the 10 plumes found in or near the boundary layer (where the 3-h average local boundary layer heights are taken from the GEOS-5 meteorology fields). This is higher than the 4-12\% of plumes found over the boundary layer between 11:10 and 13:45 LT (the MISR overpass time) in the work of Val Martin et al. (2010). However, their study excluded plumes mixed with cumulus clouds, while two of the plumes in group B were mixed with liquid water clouds (at an altitude of 3.2 and $10.3 \mathrm{~km}$ ). Soja et al. (2008) reported that during ARCTAS$\mathrm{B}$ the Canadian fires developed smoke columns reaching 5$7 \mathrm{~km}$ in altitude. The remaining difference $(25 \%$ vs. $4-12 \%$ above the BL) may reflect the later sampling time of the aircraft data, as fire intensity generally peaks in early to late afternoon, between 13:00 and 18:30 LT (Giglio, 2007; Ichoku et al., 2008).

Four of the 5 plumes downwind of the burning region were found above $3 \mathrm{~km}$, and 3 were mixed with liquid water or ice clouds, suggesting that the fresh emissions were convectively lofted or diffusively mixed upward as they traveled downwind. This could be due to the middle latitude cyclones and associated thunderstorms present over southern Canada during ARCTAS-B, leading to the lofting of biomass burning emissions in the storm updrafts (Fuelberg et al., 2010). These five plumes were all sampled by the DC8 on 4 July 2008, during the period of the most intense cloud-to-ground lightning seen during ARCTAS-B, indicative of storms with strong updrafts that can carry pollutants aloft (Fuelberg et al., 2010).

The median altitude of the aged plumes was $6.4 \mathrm{~km}$, although aged plumes were found throughout the troposphere. Two of the three "old" plumes are highly aged Siberian smoke that was transported near the pole and sampled by the DC8 over Greenland.

\subsubsection{Enhancement ratios and partitioning between $\mathrm{NO}_{\mathrm{y}}$ species}

Table 4 gives the mean enhancement ratios of $\mathrm{O}_{3}, \mathrm{NO}_{\mathrm{y}}$, $\mathrm{NO}_{\mathrm{x}}, \mathrm{HNO}_{3(\mathrm{~g})}, \mathrm{NO}_{3(\mathrm{p})}$, total PNs, PAN, and total ANs in the plumes sampled by the NASA DC8. Plumes where the given species and $\mathrm{CO}$ were not correlated were assigned a ratio of 0 for averaging.

Less than a third of the fresh and aged biomass plumes showed significant correlations between $\mathrm{O}_{3}$ and $\mathrm{CO}$, consistent with the results of Mauzerall et al. (1996) and Wofsy et al. (1992) for plumes over Canada and Alaska. The mean $\Delta \mathrm{O}_{3} / \Delta \mathrm{CO}$ of $0.5 \% \pm 1.9 \%$ in the fresh plumes was not significantly different from 0 , while the mean $\Delta \mathrm{O}_{3} / \Delta \mathrm{CO}$ for aged and old plumes were negative. These results are in contrast to several previous studies of $\Delta \mathrm{O}_{3} / \Delta \mathrm{CO}$ in boreal biomass burning plumes that have found generally positive values for $\Delta \mathrm{O}_{3} / \Delta \mathrm{CO}$ (see Table 2), with aged plumes over the Azores showing values of up to $90 \%$ (Honrath et al., 2004; Val Martin et al., 2006). However, Val Martin et al. (2006) and Real et al. (2007) both found single aged plumes with negative values ( $-40 \%$ and $-1 \%$, respectively). In addition, the analysis of TES data for Siberian fire plumes in 2006 by Verma et al. (2009) found both positive and negative enhancements of $\mathrm{O}_{3}$, consistent with our results.

The total $\mathrm{NO}_{\mathrm{y}}$ enhancement ratio shows large variability in both the fresh and aged plumes, but the mean values are similar. The mean value for old plumes is much lower, possibly due to the formation and deposition of $\mathrm{HNO}_{3(\mathrm{~g})}$ and $\mathrm{NO}_{3(\mathrm{p})}$. The average for all plumes sampled by the DC8 is $0.7 \% \pm 0.5 \%$, which is consistent with the observations of Val Martin et al. (2006) and Wofsy et al. (1992) and the modeling study of McKeen et al. (2002) summarized in Table 1.

The sum of the average enhancement ratios for the components of $\mathrm{NO}_{\mathrm{y}}$ in the fresh plumes $(1.04 \pm 1.14 \%)$ is $38 \%$ larger than the average enhancement ratio of $\mathrm{NO}_{\mathrm{y}}$, although the $1 \sigma$ uncertainty bars overlap. In contrast, the two values are nearly identical in the aged plumes $(0.50 \% \pm 0.78 \%$ and $0.51 \% \pm 0.41 \%$, respectively). While this may be due to an incomplete conversion of $\mathrm{NO}_{\mathrm{y}}$ components on the catalyst surface, the discrepancy is likely due to the uncertainty in the linear regressions used to calculate the enhancement ratios of individual species in the fresh smoke plumes. In several plumes, the correlation of $\mathrm{NO}_{\mathrm{y}}$ with $\mathrm{CO}$ is stronger than the correlation of $\mathrm{NO}_{\mathrm{x}}$ and other components with $\mathrm{CO}$, and the slopes of the components are correspondingly less certain, so the sums of these enhancement ratios are more uncertain than the slope of $\mathrm{NO}_{\mathrm{y}}$ itself.

The mean fresh smoke $\mathrm{NO}_{\mathrm{x}}$ emission ratio of $0.34 \% \pm 0.52 \%$ is significantly lower than the estimates of Nance et al. (1993) and Goode et al. (2000) of 1.2\% (for $\mathrm{NO}_{\mathrm{x}}$ ) and 1.4-1.8\% (for NO only), respectively. There are two likely explanations for this difference. First, there may have been a larger fraction of smoke from smoldering fires in the ARCTAS observations. The reported average MCE 
Table 4. Enhancement ratios $(\mathrm{mol} / \mathrm{mol})$ for boreal plumes observed by NASA DC8 during ARCTAS.

\begin{tabular}{|c|c|c|c|c|c|}
\hline Ratio & Subcategory & Age classification & Number correlated ${ }^{a}$ & $\operatorname{Mean} \pm 1 \sigma^{a}(\%)$ & Range (\%) \\
\hline \multirow[t]{3}{*}{$\Delta \mathrm{O}_{3} / \Delta \mathrm{CO}$} & & Fresh & 4 of 16 & $+0.5 \pm 1.9$ & -3.2 to +5.2 \\
\hline & & Aged & 4 of 15 & $-6 \pm 28$ & -94 to +34 \\
\hline & & Old & 1 of 3 & $-7 \pm 12$ & -20 \\
\hline \multirow[t]{3}{*}{$\Delta \mathrm{NO}_{\mathrm{y}} / \Delta \mathrm{CO}$} & & Fresh & 14 of 16 & $0.75 \pm 0.52$ & 0.43 to 1.49 \\
\hline & & Aged & 11 of 15 & $0.51 \pm 0.41$ & 0.26 to 1.36 \\
\hline & & Old & 1 of 3 & $0.12 \pm 0.21$ & 0.36 \\
\hline \multirow{3}{*}{$\Delta \mathrm{NO}_{\mathrm{X}} / \Delta \mathrm{CO}$} & & Fresh & 10 of 16 & $0.34 \pm 0.52$ & 0.02 to 1.80 \\
\hline & & Aged & 6 of 15 & $0.05 \pm 0.12$ & -0.11 to 0.44 \\
\hline & & Old & 0 of 3 & 0 & 0 \\
\hline \multirow[t]{3}{*}{$\Delta \mathrm{HNO}_{3(\mathrm{~g})} / \Delta \mathrm{CO}$} & & Fresh & 1 of 16 & -0.004 & 0.07 \\
\hline & & Aged & 3 of 15 & $-0.01 \pm 0.10$ & -0.33 to 0.18 \\
\hline & & Old & 0 of 3 & 0 & 0 \\
\hline \multirow[t]{3}{*}{$\Delta \mathrm{NO}_{3(\mathrm{p})} / \Delta \mathrm{CO}$} & & Fresh & 11 of 16 & $0.18 \pm 0.14$ & 0.14 to 0.38 \\
\hline & & Aged & 7 of 15 & $0.06 \pm 0.10$ & 0.01 to 0.38 \\
\hline & & Old & 0 of 3 & 0 & 0 \\
\hline \multirow[t]{6}{*}{$\Delta$ Total PNs/ $\Delta \mathrm{CO}$} & & Fresh & 14 of 16 & $0.45 \pm 0.38$ & 0.22 to 1.51 \\
\hline & & Aged & 11 of 15 & $0.31 \pm 0.31$ & 0.22 to 1.14 \\
\hline & & Old & 0 of 3 & 0 & 0 \\
\hline & $\triangle P A N / \triangle C O$ & Fresh & 13 of 16 & $0.34 \pm 0.35$ & 0.09 to 1.43 \\
\hline & & Aged & 12 of 15 & $0.35 \pm 0.26$ & 0.11 to 0.87 \\
\hline & & Old & 2 of 3 & $0.28 \pm 0.36$ & 0.16 to 0.68 \\
\hline \multirow[t]{3}{*}{$\Delta$ Total ANs/ $\Delta \mathrm{CO}$} & & Fresh & 8 of 16 & $0.07 \pm 0.10$ & 0.06 to 0.27 \\
\hline & & Aged & 6 of 15 & $0.09 \pm 0.15$ & 0.08 to 0.46 \\
\hline & & Old & 0 of 3 & 0 & 0 \\
\hline
\end{tabular}

${ }^{a}$ For averaging, plumes where the correlation was not significant are assumed to have an enhancement ratio of 0.

for the Nance et al. (1993) and Goode et al. (2000) fires were $92.3 \%$ and $92.8 \%$, respectively, suggesting that they sampled primarily flaming combustion. Second, Nance et al. (1993) and Goode et al. (2000) measured $\mathrm{NO}_{\mathrm{x}}$ very close to the fire source, before the rapid processing of $\mathrm{NO}_{\mathrm{x}}$ emissions into other $\mathrm{NO}_{\mathrm{y}}$ species seen in the Lake McKay plumes.

Gaseous $\mathrm{HNO}_{3}$ is uncorrelated with $\mathrm{CO}$ in all but four plumes. Fine aerosol nitrate $\left(\mathrm{NO}_{3(\mathrm{p})}\right)$ is positively correlated with $\mathrm{CO}$ in the fresh plumes, but the enhancement ratio drops substantially in the aged plumes. The low correlation with $\mathrm{HNO}_{3(\mathrm{~g})}$ and the loss of $\mathrm{NO}_{3(\mathrm{p})}$ over time can be explained by the condensation and evaporation of nitrate combined with the deposition of both $\mathrm{HNO}_{3(\mathrm{~g})}$ and $\mathrm{NO}_{3(\mathrm{p})}$. $\mathrm{NH}_{4} \mathrm{NO}_{3}$ can form in the concentrated fresh plume from the

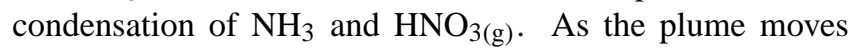
downwind and dilutes, $\mathrm{NH}_{4} \mathrm{NO}_{3}$ may evaporate into $\mathrm{NH}_{3}$ and $\mathrm{HNO}_{3(\mathrm{~g})}$, reducing the enhancement ratio for $\mathrm{NO}_{3(\mathrm{p})}$. The $\mathrm{HNO}_{3(\mathrm{~g})}$ formed by the evaporation is then rapidly deposited to the surface. DeCarlo et al. (2008) saw similar behavior of $\mathrm{HNO}_{3(\mathrm{~g})}$ and $\mathrm{NO}_{3(\mathrm{p})}$ in the urban pollution plume from Mexico City.
In the fresh smoke plumes the average enhancement of $\mathrm{NO}_{3(\mathrm{p})}$ is roughly half of the PAN enhancement. This suggests that in the fresh Canadian plumes twice as much of the initial $\mathrm{NO}_{\mathrm{x}}$ emissions were converted to PAN as to $\mathrm{HNO}_{3(\mathrm{~g})}$. In the (primarily Siberian) aged plumes, PAN accounted for $69 \%$ of the $\mathrm{NO}_{\mathrm{y}}$, with $\mathrm{NO}_{\mathrm{x}}$ accounting for $11 \%$ and $\mathrm{NO}_{3(\mathrm{p})}$ accounting for $12 \%$.

We used the above enhancement ratios of $\mathrm{NO}_{\mathrm{x}}, \mathrm{PAN}$, and total inorganic nitrate (the sum of $\mathrm{HNO}_{3(\mathrm{~g})}$ and $\mathrm{NO}_{3(\mathrm{p})}$ ) to derive new emission factors for use in GEOS-Chem. In general, emission factors may be calculated from emission ratios using the equation:

$\mathrm{EF}_{\mathrm{i}}=\mathrm{M}_{\mathrm{i}} \cdot \mathrm{ER}_{i} \cdot(1-\mathrm{MCE}) \cdot \mathrm{f}_{\mathrm{C}} / \mathrm{M}_{\mathrm{C}}$

where $\mathrm{EF}_{\mathrm{i}}$ is the emission factor reported throughout this paper as gi per kg dry matter burned (g i/kg DM), where $\mathrm{i}$ indicates the species whose molecular weight was used to calculate the emission factor. $M_{i}$ is the molecular weight of species $\mathrm{i}(\mathrm{g} / \mathrm{mol}), \mathrm{ER}_{\mathrm{i}}$ is the emission ratio of species $\mathrm{i}$ ( $\mathrm{mol} / \mathrm{mol} \mathrm{CO}$ ), MCE is the modified combustion efficiency (unitless, assumed to be $90 \% \pm 5 \%$ ) $\mathrm{f}_{\mathrm{C}}$ is the mass fraction of 
Table 5. Extratropical biomass burning emissions for the three model scenarios.

\begin{tabular}{lccc}
\hline & GC-ORIG & GC-SENS & GC-NOFIRE \\
\hline Percentage of Biomass Burned (relative to FLAMBE) & 100 & 37.5 & 0 \\
$\mathrm{NO}_{\mathrm{x}}$ Emission Factor (g NO/kg DM) & $3.0^{\mathrm{a}}$ & 0.42 & - \\
$\mathrm{PAN}$ Pseudo-emission Factor (g PAN/kg DM) & 0 & 1.69 & - \\
$\mathrm{HNO}_{3(\mathrm{~g})}$ Pseudo-emission Factor (g HNO $\left.3 / \mathrm{kg} \mathrm{DM}\right)$ & 0 & 0.47 & - \\
\hline
\end{tabular}

a Andreae and Merlet (2001)

carbon in the biomass (assumed to be $0.5 \mathrm{~kg} \mathrm{C} / \mathrm{kg} \mathrm{DM}$ ) and $\mathrm{M}_{\mathrm{C}}$ is the molecular weight of carbon $(0.012 \mathrm{~kg} \mathrm{C} / \mathrm{mol})$.

We assumed that the PAN and $\mathrm{NO}_{3(\mathrm{p})}$ detected in the fresh plumes are the result of post-emission chemistry converting the initial $\mathrm{NO}_{\mathrm{x}}$ emissions from the flame front into these species, as was seen in the Lake McKay smoke plume in Sect. 3.1. With this assumption, we calculate an emission factor for $\mathrm{NO}_{\mathrm{x}}$ of $1.06 \mathrm{~g} \mathrm{NO} / \mathrm{kg}$ DM for ARCTAS-B, much lower than the value of $3.0 \mathrm{~g} \mathrm{NO} / \mathrm{kg}$ DM from Andreae and Merlet (2001) for extratropical forest fires currently used in GEOS-Chem. There are two potential explanations for this discrepancy. First, the mass fraction of nitrogen in the fuel burned in ARCTAS-B may have been lower than in the studies considered by Andreae and Merlet (2001). Second, the fraction of smoldering combustion (instead of flaming) in ARCTAS-B may have been higher than in the studies used by Andreae and Merlet (2001). Of the 10 papers that Andreae and Merlet (2001) used to derive an average $\mathrm{NO}_{\mathrm{x}}$ emission factor for extratropical forest fires, 8 had MCE values above $90 \%$ (consistent with primarily flaming combustion), while only 2 had MCE values below 90\% (consistent with primarily smoldering combustion). Thus their mean emission factor potentially overestimates the influence of flaming combustion on $\mathrm{NO}_{\mathrm{x}}$ emissions from extratropical fires.

The rapid plume chemistry that converts the initial $\mathrm{NO}_{\mathrm{x}}$ emissions from biomass burning occurs at too small a scale to be simulated successfully in global models. To incorporate the effects of this post-emission chemistry, we derived pseudo-emission factors by replacing the emission ratio in Eq. (1) with the observed enhancement ratio of these species in fresh plumes, given in Table 4. These factors represent the effect of the emission of $\mathrm{NO}_{\mathrm{x}}$ from the flame front and the subsequent plume chemistry in the first few tens of minutes after emission. Based on the enhancement ratios observed in the fresh smoke plumes during ARCTAS-B, we calculate a pseudo-emission factor for $\mathrm{NO}_{\mathrm{x}}$ of $0.42 \pm 0.66 \mathrm{~g}$ $\mathrm{NO} / \mathrm{kg} \mathrm{DM}$, as $60 \%$ of the initial $\mathrm{NO}_{\mathrm{x}}$ is converted into other $\mathrm{NO}_{\mathrm{y}}$ species shortly after emission. Similarly, the pseudo-emission factors for PAN and total inorganic nitrate are $1.69 \pm 1.82 \mathrm{~g} \mathrm{PAN} / \mathrm{kg} \mathrm{DM}$ and $0.47 \pm 0.37 \mathrm{~g} \mathrm{HNO}_{3(\mathrm{~g})} / \mathrm{kg}$ $\mathrm{DM}$, respectively. These new factors are used in the GCSENS model run discussed below.

\subsection{GEOS-chem model results}

\subsubsection{Comparison with DC8 observations}

Figure 6 compares the model simulations to ARCTAS-B observations of $\mathrm{CO}$, ozone, $\mathrm{NO}_{\mathrm{x}}, \mathrm{PAN}, \mathrm{NO}_{3(\mathrm{p})}$ and $\mathrm{HNO}_{3(\mathrm{~g})}$. The black line is the median of all of the observations by the NASA DC8 on 29 June-10 July binned every kilometer in altitude. The red line is the median profile of the GCORIG model run, while the green line represents the GCSENS model run and the blue line represents the results of the GC-NOFIRE model run. The different parameters for these three model runs are summarized in Table 5. There are three major differences between the GC-SENS run and the GC-ORIG run. First, we reduced the amount of biomass consumed by each extratropical fire to $37.5 \%$ of the FLAMBE estimate to match the DC8 observations of $\mathrm{CO}$, as discussed below. This procedure assumes that the default emission factor for CO used in the model (106 g CO/kg DM from Andreae and Merlet (2001)) is correct, that all of the error is thus in the quantity of biomass burned, and that the error is the same for all extratropical fires. This results in a proportional reduction of the emissions of all species emitted by extratropical fires. Second, the emission factor for the sum of all model-emitted $\mathrm{NO}_{\mathrm{y}}$ species from biomass burning (i.e., $\mathrm{NO}_{\mathrm{x}}$, PAN, $\mathrm{NO}_{3(\mathrm{p})}$ and $\mathrm{HNO}_{3(\mathrm{~g})}$ was reduced (from $3.0 \mathrm{~g} \mathrm{NO} / \mathrm{kg}$ DM to $1.06 \mathrm{~g} \mathrm{NO} / \mathrm{kg} \mathrm{DM}$ ) to be in line with the ARCTAS-B observations. Third, the emissions of $\mathrm{NO}_{\mathrm{y}}$ were partitioned among the three species to simulate the sub-grid scale postemission chemistry observed in ARCTAS-B. Thus, the emission factor of $\mathrm{NO}_{\mathrm{x}}$ from extratropical fires was reduced from $3.0 \mathrm{~g} \mathrm{NO} / \mathrm{kg}$ DM to $0.42 \mathrm{~g} \mathrm{NO} / \mathrm{kg} \mathrm{DM}$ starting on 15 June 2008. Similarly, pseudo-emission factors for PAN and total inorganic nitrate were increased from 0 to $1.69 \mathrm{~g} \mathrm{PAN} / \mathrm{kg}$ $\mathrm{DM}$ and $0.47 \mathrm{~g} \mathrm{HNO}_{3(\mathrm{~g} /} / \mathrm{kg} \mathrm{DM}$, respectively. The total inorganic nitrate pseudo-emission factor includes emissions of both $\mathrm{NO}_{3(\mathrm{p})}$ and $\mathrm{HNO}_{3(\mathrm{~g})}$; the model equilibrates the nitrate between phases after emission. It should be noted that this is only one possible set of assumptions about biomass consumed and emission factors that could lead to the same emission rates; our choices above reflect our attempt to make the minimum number of adjustments to the model required to better match the observations. In the GC-NOFIRE case, all 

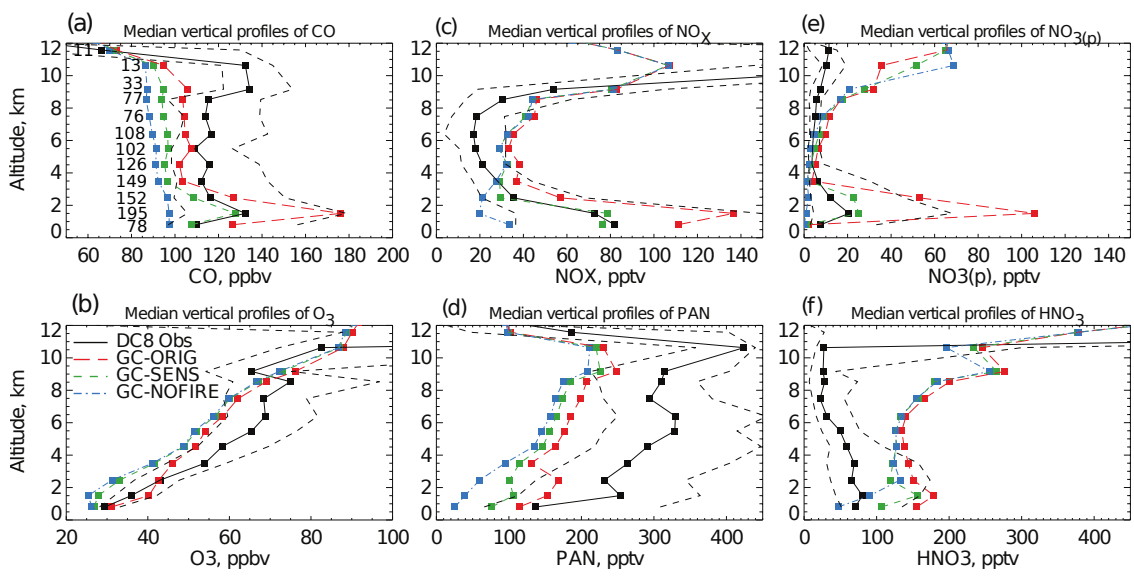

Fig. 6. Median vertical profiles of (a) $\mathrm{CO}$, (b) ozone, (c) $\mathrm{NO}_{\mathrm{x}}$, (d) PAN, (e) fine aerosol nitrate $\left(\mathrm{NO}_{3}(\mathrm{p})\right.$ ) and (f) HNO 3 (g) during ARCTASB. The solid black line is the DC8 observations (the dashed black lines are the 25th and 75th percentiles of the observations), the red line is the results of the original GEOS-Chem model run (GC-ORIG), the green line is from the model emissions sensitivity study (GC-SENS) and the blue line is when extratropical fire emissions are set to 0 (GC-NOFIRE). The numbers in the profile of CO represent the number of observations at each altitude level.

model emissions from extratropical fires were set to 0 starting on 15 June 2008.

Figure 6a shows the observed and modeled CO profiles. All model runs show a 10-20 ppb underestimate of $\mathrm{CO}$ above $3 \mathrm{~km}$. GC-ORIG greatly overestimated the median profile in the lower troposphere below $3 \mathrm{~km}$, the area most sensitive to recent Canadian biomass burning emissions. Reducing the total biomass consumed to $3 / 8$ of their original values, as in GC-SENS, better matches the observations below $3 \mathrm{~km}$. However, the GC-ORIG results are closer to observations above $3 \mathrm{~km}$, suggesting that the FLAMBE emissions may be more accurate for the Siberian fires sampled at higher altitudes than they are for the local Canadian emissions. Comparing the GC-SENS profile with the GC-NOFIRE profile shows that extratropical fire emissions during ARCTAS-B had a substantial impact on the median $\mathrm{CO}$ profile in this region, up to $40 \mathrm{ppb}$ in the boundary layer, and 5-10 ppb above. The cause of the underestimate of $\mathrm{CO}$ above $3 \mathrm{~km}$ is not clear, and it may be related to deficiencies in the transport of $\mathrm{CO}$ from mid-latitude source regions or an underestimate of the amount of biomass burning emissions injected above the boundary layer. For example, Fisher et al. (2010) found that anthropogenic emissions of $\mathrm{CO}$ from Asia and Europe in GEOS-Chem had to be increased (by $18 \%$ and $52 \%$, respectively) to match observations of $\mathrm{CO}$ in the Arctic during ARCTAS-A.

Figure $6 \mathrm{~b}$ shows the profiles for ozone. All three model runs show an underestimate of 10-20 ppb ozone above $3 \mathrm{~km}$, which may be caused by an underestimate of stratospherictropospheric exchange in the model, an underestimate in the amount of ozone transported from the mid-latitudes, or errors in the modeled photochemical production and loss of ozone in the Arctic free troposphere. While GC-ORIG shows the best match to the observations of ozone below $3 \mathrm{~km}$, the match is degraded when the revised emissions estimates are used as in GC-SENS. We also see very little difference between the GC-SENS model results and the GCNOFIRE results. This suggests that fire emissions during the ARCTAS-B period had little to no effect on ozone, consistent with the near-zero enhancement of ozone observed in the boreal biomass burning plumes sampled by the DC8 (see Sect. 3.2 above) and seen in the TES special observations (see Sect. 3.3.3 below).

About half of the difference in ozone between the GCORIG and GC-SENS cases is caused by the reduction of the amount of biomass consumed with the other half caused by the reduction of the total $\mathrm{NO}_{\mathrm{y}}$ emission factor for extratropical forests from $3.0 \mathrm{~g} \mathrm{NO} / \mathrm{kg} \mathrm{DM}$ to $1.06 \mathrm{~g} \mathrm{NO} / \mathrm{kg} \mathrm{DM}$. In contrast, the partitioning of the emitted $\mathrm{NO}_{\mathrm{y}}$ between $\mathrm{NO}_{\mathrm{x}}$, PAN, $\mathrm{NO}_{3(\mathrm{p})}$ and $\mathrm{HNO}_{3}$ by subgrid scale plume chemistry has little impact on the modeled median ozone concentration during ARCTAS-B. In GC-SENS, the model emitted PAN is rapidly converted back to $\mathrm{NO}_{\mathrm{x}}$ by the model chemistry. However, as we are only emitting smoke into the boundary layer, we may be underestimating the impact of in-plume PAN formation on ozone. Leung et al. (2007) found that emitting a fraction of smoke above the boundary layer could have significant impacts on ozone, even when the $\mathrm{NO}_{\mathrm{y}}$ is all emitted as $\mathrm{NO}_{\mathrm{x}}$, because of the longer lifetime of PAN above the boundary layer. Further work is needed on the impact of the rapid formation of PAN in fresh smoke plumes on ozone when the smoke is injected above the boundary layer.

Figure $6 \mathrm{c}$ shows the profiles for $\mathrm{NO}_{\mathrm{x}}$. While all the model runs overestimate the $\mathrm{NO}_{\mathrm{x}}$ profile above $4 \mathrm{~km}$, the GC-SENS 

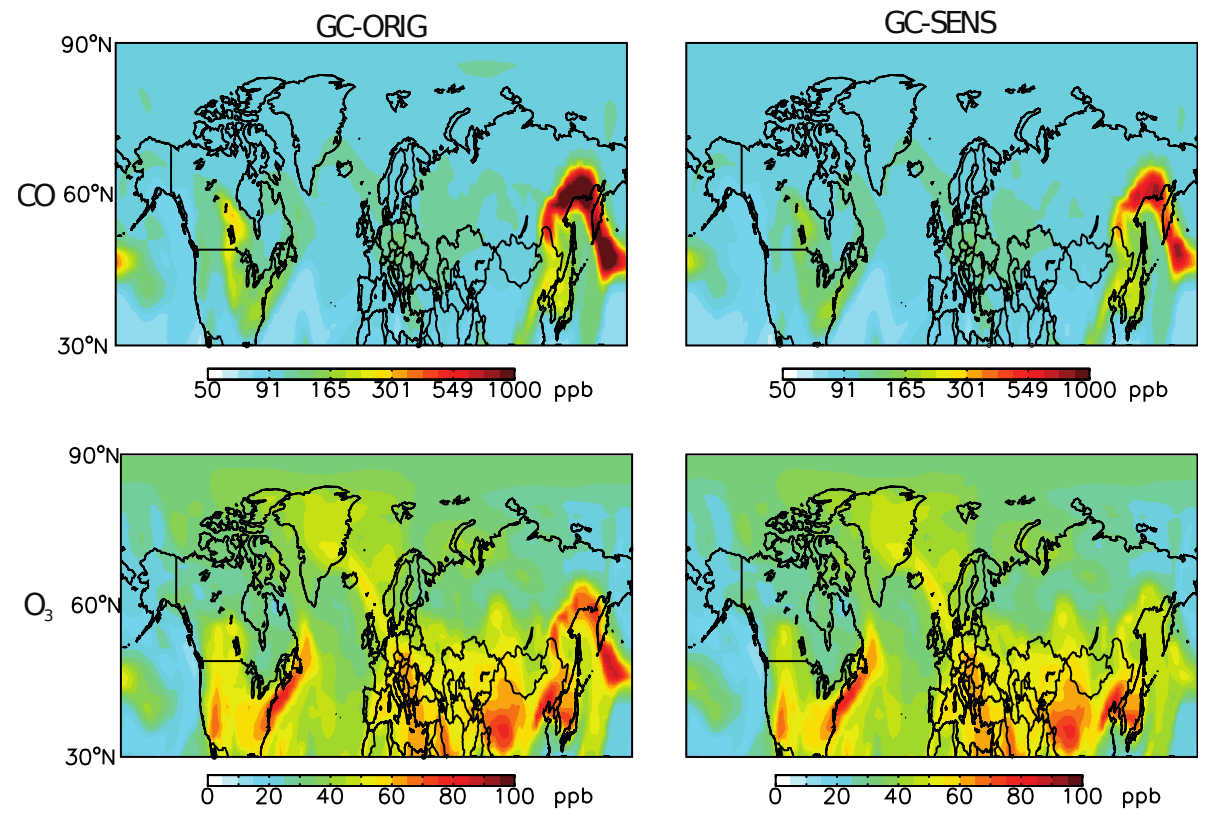

Fig. 7. Mixing ratios of $\mathrm{CO}$ and ozone at $850 \mathrm{hPa}$ in the original GEOS-Chem simulation (GC-ORIG) and in the emissions sensitivity case (GC-SENS) for 4 July 2008. Note that the different emissions started on 15 June 2008.

run shows the best match to the observed profile of $\mathrm{NO}_{\mathrm{x}}$ below $3 \mathrm{~km}$. This same effect is seen in the profile for $\mathrm{NO}_{3(\mathrm{p})}$ in Fig. 6e. This adds confidence to the modified estimates of biomass consumed and emission factors of the GC-SENS run.

Figure $6 \mathrm{~d}$ and $\mathrm{f}$ shows the vertical profiles for PAN and $\mathrm{HNO}_{3(\mathrm{~g})}$, respectively. As expected, reducing the modeled emissions of $\mathrm{CO}$ and $\mathrm{NO}_{\mathrm{y}}$ species reduces the modeled concentrations of both of these species in the Arctic. However, all model runs substantially underestimate PAN and overestimate $\mathrm{HNO}_{3(\mathrm{~g})}$ relative to the observations, suggesting that the model chemistry is incorrectly modeling the partitioning of $\mathrm{NO}_{\mathrm{y}}$ in the Arctic troposphere or is underestimating the transport of PAN from midlatitudes to the Arctic. Similar underestimates of PAN and overestimates of $\mathrm{HNO}_{3(\mathrm{~g})}$ are seen in GEOS-Chem benchmark simulations when compared with data from the ABLE-3A (Wofsy et al., 1992) and ABLE-3B (Mauzerall et al., 1996) campaigns over Alaska and Canada, respectively (not shown), while GEOS-Chem was fairly successful at modeling PAN concentrations in the ICARTT campaign over the eastern United States and North Atlantic (Hudman et al., 2007). $\mathrm{HNO}_{3(\mathrm{~g})}$ is often overestimated in global models such as GEOS-Chem, and is thought to be due to insufficient precipitation scavenging (Bey et al., 2001).

The underestimate of PAN in the model is likely caused by a similar underestimate of acetaldehyde relative to the PTRMS and GC-MS observations. Although the two measurements give different results for the median vertical pro- file of acetaldehyde, both show significantly higher levels than the model above $3 \mathrm{~km}$ (40 to $125 \mathrm{ppt}$ higher than the model). This underestimate of acetaldehyde then leads to an underestimate of the rate of acetyl peroxy radical formation, and thus to an underestimate of PAN formation at high latitudes. Results from ICARTT do not show a similar problem because isoprene emissions in southeastern United States provide a large source of acetaldehyde within the model, allowing significant PAN formation downwind of this region. The underestimate of acetaldehyde and PAN may be linked to the underestimate of ozone seen in Fig. $6 \mathrm{~b}$ - if the model is overestimating $\mathrm{HNO}_{3}$ formation relative to PAN, that could lead to an underestimate in the amount of ozone formed.

\subsubsection{Modeled arctic CO and ozone}

Figure 7 shows the daily mean mixing ratios of $\mathrm{CO}$ and ozone over the northern extratropics at $850 \mathrm{hPa}$ for both the GCORIG and GC-SENS case on 4 July 2008. Results are presented for this date as this corresponds with 3 strong $\mathrm{CO}$ plumes detected in TES special observations, as discussed in Sect. 3.3.3 below. Figure 8 shows the $\mathrm{CO}$ and ozone concentrations at $510 \mathrm{hPa}$ for both model runs on this date, and Fig. 9 shows the percentage differences between the two model runs caused by the revised estimates of emissions from extratropical fires.

The main features in the CO maps of Figs. 7 and 8 are the strong plume of $\mathrm{CO}$ from biomass burning in Siberia that crosses the northern Pacific and the elevated levels of $\mathrm{CO}$ over the burning region in Canada. Both features are 

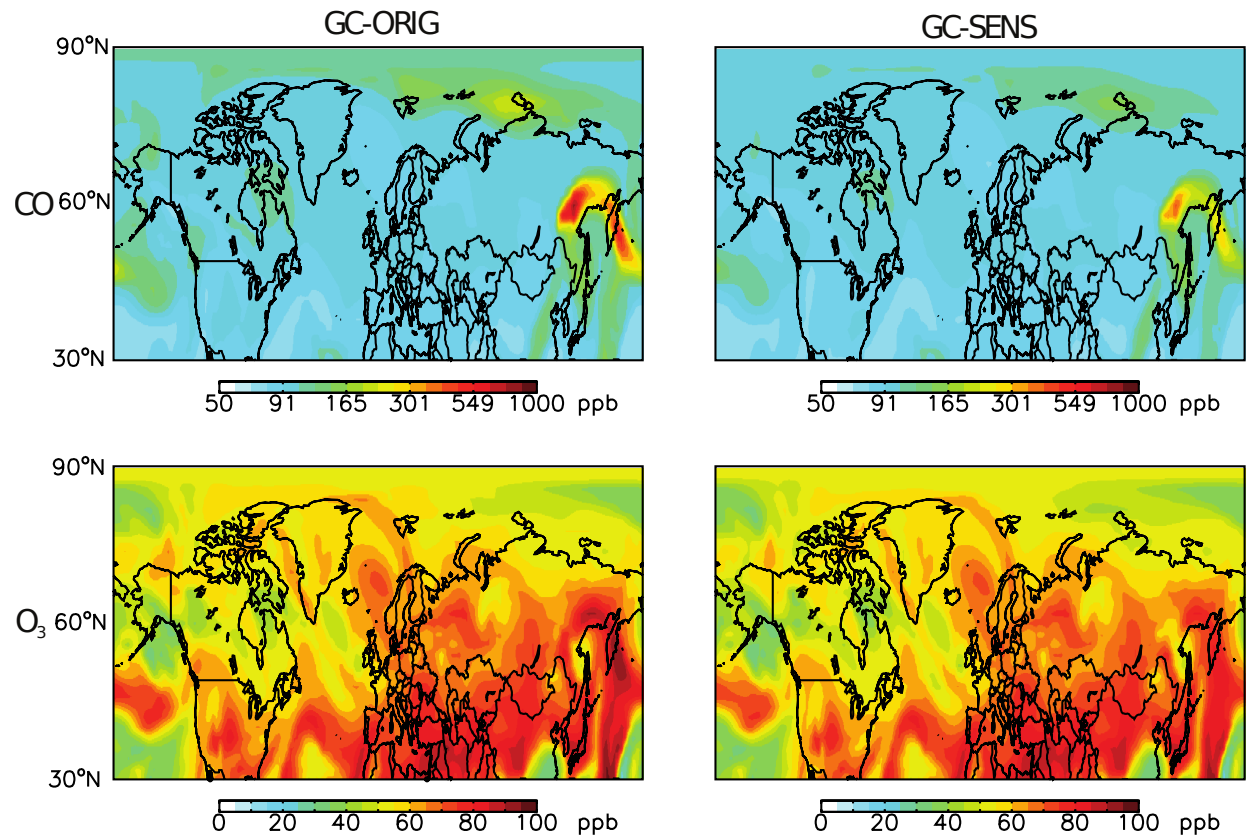

Fig. 8. Mixing ratios of $\mathrm{CO}$ and ozone at $510 \mathrm{hPa}$ in the original GEOS-Chem simulation (GC-ORIG) and in the emissions sensitivity case (GC-SENS) for 4 July 2008. Note that the different emissions started on 15 June 2008.

$850 \mathrm{hPa}$
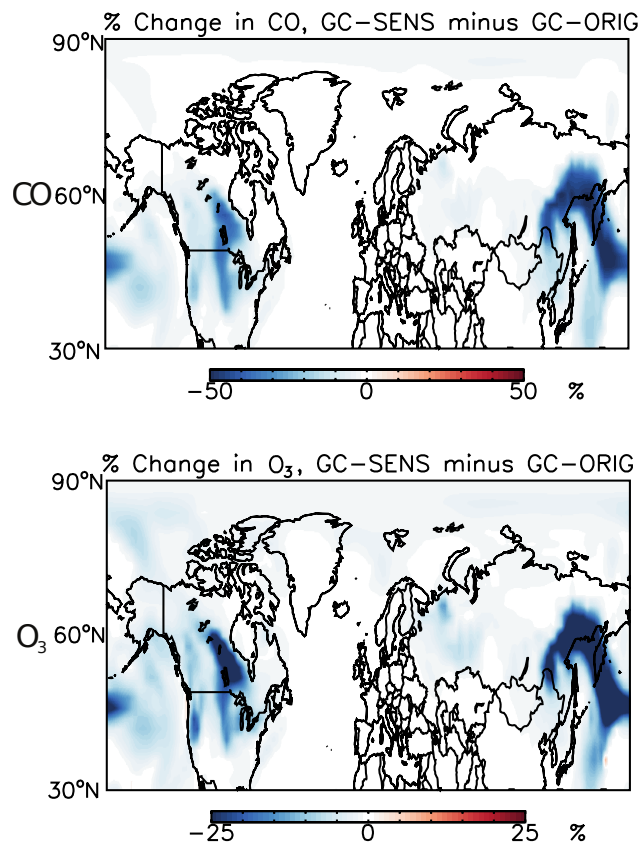

$510 \mathrm{hPa}$

\% Change in CO, GC-SENS minus GC-ORIG

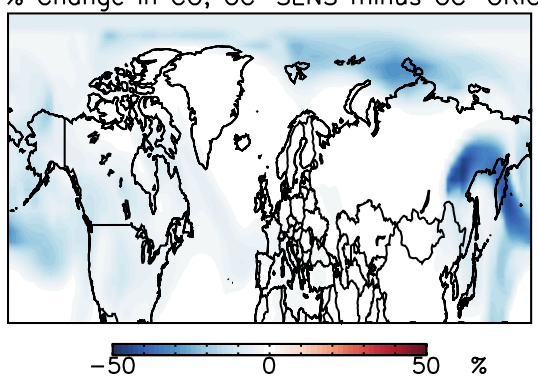

\% Change in $\mathrm{O}_{3}, \mathrm{GC}-\mathrm{SENS}$ minus GC-ORIC

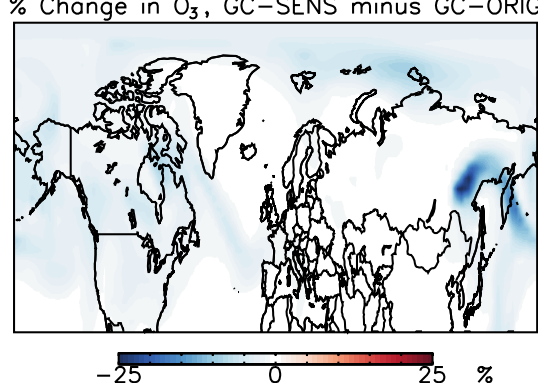

Fig. 9. Percentage differences between the mixing ratios of $\mathrm{CO}$ and ozone at $850 \mathrm{hPa}$ and $510 \mathrm{hPa}$ in the emissions sensitivity case (GCSENS) minus the mixing ratios in the original GEOS-Chem simulation (GC-ORIG) for 4 July 2008. Note that the different emissions started on 15 June 2008. 

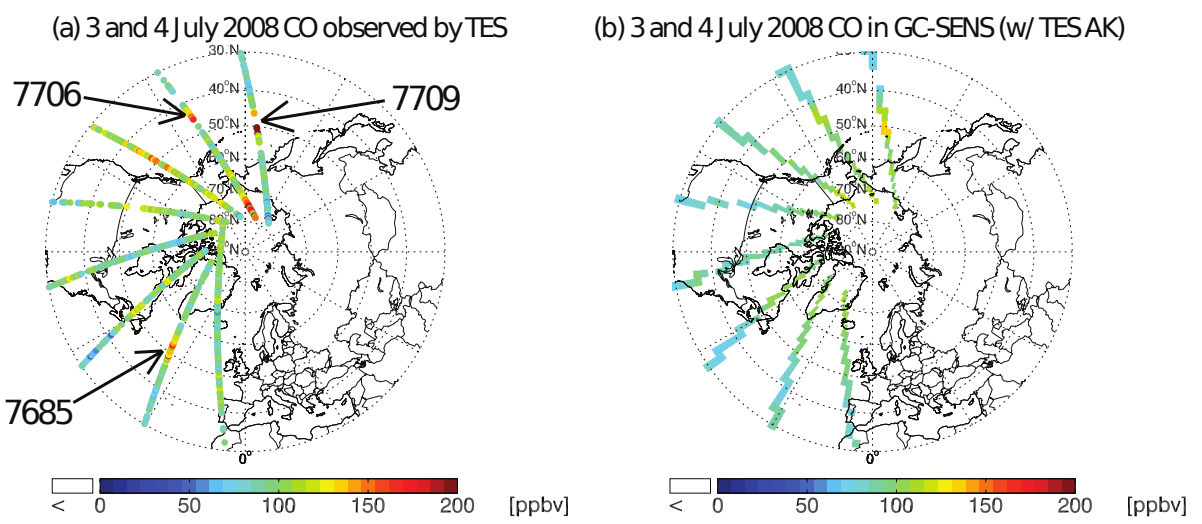

(c) 3 and 4July $2008 \mathrm{O}_{3}$ observed byTES
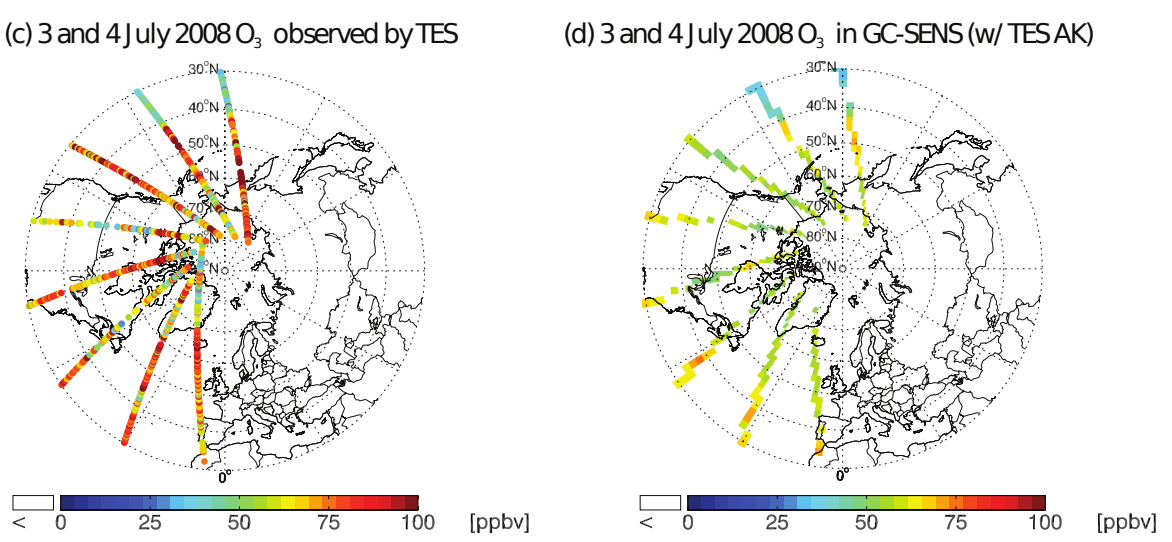

Fig. 10. Maps of (a) CO and (c) ozone mixing ratio at $510 \mathrm{hPa}$ from TES special observations on 3 and 4 July 2008 compared to plots of three-hour average (b) $\mathrm{CO}$ and (d) ozone mixing ratio at $510 \mathrm{hPa}$ from the GC-SENS simulations with the TES averaging kernel applied.

substantially reduced in the GC-SENS simulation, due to the 5/8 lower emissions of $\mathrm{CO}$ from biomass burning in the GC-SENS model. In addition, while the GC-ORIG results show strong ozone enhancements collocated with the biomass burning $\mathrm{CO}$ at 850 and $510 \mathrm{hPa}$, the GC-SENS model results show a much smaller impact of biomass burning emissions on ozone.

Figure 9 shows that the modeled $\mathrm{CO}$ mixing ratio decreases with the new emissions - by about $50 \%$ downwind of the Siberian fires and 5-10\% in the rest of the Arctic due to the lower estimate of biomass consumed. Ozone is also is lower throughout the Arctic, with large reductions of $20 \%$ or more immediately downwind of the Siberian fires, and smaller reductions of about 5\% through large areas of the Arctic. The decrease in ozone is caused by the reduced emissions of $\mathrm{NO}_{\mathrm{x}}$ leading to lower photochemical production of ozone in the smoke plumes and higher net photochemical loss of ozone in the Arctic troposphere.

\subsubsection{Comparison with TES special observations}

Figure 10 shows the TES special observations at $510 \mathrm{hPa}$ for ozone and CO on 3 and 4 July 2008, a period where TES encountered two plumes over the North Pacific and one over the
North Atlantic. We also show the results from the GC-SENS model run at that pressure level that have been processed with the TES averaging kernel. Figure 10a shows a strong plume of CO from the Siberian fires in two TES transects, 7706 and 7709 , over the North Pacific, and a plume from the Canadian fires over the North Atlantic in transect 7685. All three plumes are weaker in the GC-SENS model results.

Figure 11 shows the mixing ratios of $\mathrm{CO}$ and ozone from the TES observations and from the GC-ORIG and GC-SENS output with the TES averaging kernel applied for run 7685 (3 July) over the North Atlantic. The CO plume is much stronger in the TES data than in the model results. TES ozone increases at the northern and southern edges of the plume, but dips in the plume center. The model results, in contrast, show no change in ozone in the smoke plume.

Figure 12 shows the four other plumes from North American boreal biomass burning observed by TES between 15 June and 15 July 2008. As the new emissions in the GCSENS model run started on 15 June, the earlier retrievals (e.g. 7472 on 17 June) show less difference between the GCORIG and GC-SENS model runs than later retrievals (e.g. 7793 on 9 July). Only one of these plumes, from TES run 7656 (1 July), shows a significant increase in ozone 

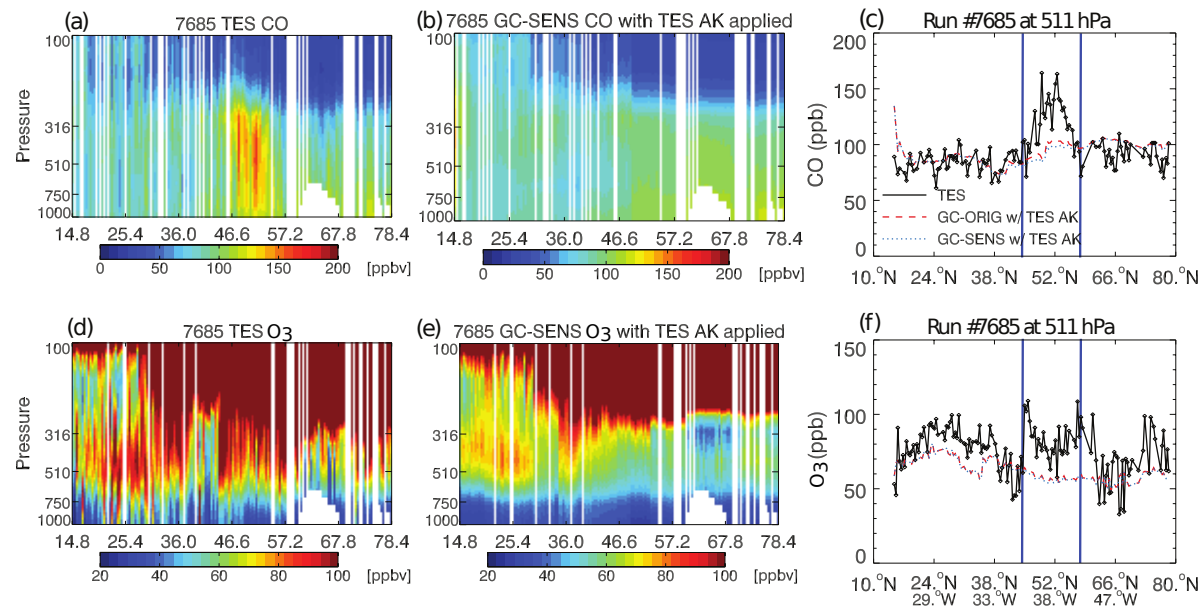

Fig. 11. Plots of CO and ozone mixing ratio along the TES orbit track for TES run 7685 on 3 July 2008. (a) and (d) are the TES retrievals for CO and ozone, respectively, while (b) and (e) are the GC-SENS model results along the TES orbit track with the TES averaging kernel (AK) applied. (c) and (f) show the mixing ratios of $\mathrm{CO}$ and ozone, respectively, at $510.9 \mathrm{hPa}$ from the TES retrieval (black solid line), the GC-ORIG model run with the TES AK applied (red dashed line), and the GC-SENS emission sensitivity study with the TES AK applied (blue dotted line).The solid blue lines represent the approximate edges of the plume.

associated with the smoke plume. However, the GC-ORIG and GC-SENS model runs show a decrease in ozone at this location.

Figure 13 and 14 show the mixing ratios of $\mathrm{CO}$ and ozone from the TES observations and from GEOS-Chem for the plumes over the North Pacific shown in Fig. 10. We see that the $\mathrm{CO}$ plume near $45^{\circ} \mathrm{N}$ in run 7706 is in the same location in TES and the model, albeit with different magnitudes. Ozone increases at the southern edge of the plume in both the TES retrievals and the model, but ozone continues to increase in the observations but not in the model results. The ozone feature seen by TES has a much larger extent than the plume.

The results for ozone in run 7709 are similar to those for run 7706 , likely reflecting the fact that the two retrievals are sampling the same plume, with run 7709 further upwind. However, here the increase in ozone seems to begin a little south of the CO plume in TES and the model. In TES, the high ozone continues north, outside of the plume, a feature not seen in the model. The high ozone to $\mathrm{CO}$ ratio north of the plume suggests that this increased ozone may be due to a stratospheric intrusion that is not correctly simulated in the model. Intrusions of stratospheric air frequently occurs within the same midlatitude cyclones that transport polluted plumes across the Pacific. Descending dry air within these cyclones can have a significant stratospheric component, and can reach the midtroposphere (Cooper et al., 2004). This intermingling complicates the interpretation of any observed ozone/CO relationship, since it is difficult to separate the portions due to stratospheric air and those due to the polluted plume (Nowak et al., 2004). Thus, we cannot tell how much of the ozone increase seen in Fig. 13 for TES run 7706 is due to ozone formed within the smoke plume and how much is due to a descent of stratospheric air.

Figures 15 and 16 show the $\mathrm{CO}$ and ozone mixing ratios measured by TES for 15 biomass burning plumes from Siberian burning observed between 15 June and 15 July 2008. We find that, as in the North American plumes from Figure 12, ozone is only occasionally elevated in the $\mathrm{CO}$ plumes and even when it is, both model runs show similar ozone levels, suggesting the ozone is not from the fires (see, for example, run 7741). This result is consistent with the NASA DC8 observations discussed in Sect. 3.2, with the study of Verma et al. (2009) who used TES to study ozone formation in Siberian smoke plumes in 2006, and with the work of Mauzerall et al. (1996), who suggested that ozone formation in the plumes had a negligible impact on the Arctic tropospheric ozone budget. However, this is in contrast to several previous studies showing ozone enhancements in highly aged boreal biomass burning plumes observed over the Azores (Honrath et al., 2004; Val Martin et al., 2006; Pfister et al., 2006).

Given that the NASA DC8 data also shows little ozone formation, but rapid PAN formation, in fresh Canadian smoke plumes, it is possible that the high ozone enhancement ratios occasionally observed over the Azores may be the result of increased photochemical production of ozone that occurs when the biomass burning plumes are transported southward and descend, leading to the conversion of PAN to $\mathrm{NO}_{\mathrm{x}}$ and rapid photochemical production of ozone in the relatively warmer mid-latitude location of the Azores. However, even over the Azores boreal smoke plumes are occasionally depleted in ozone, consistent with our results (Val Martin et al., 2006; Real et al., 2007). Another possible explanation is 

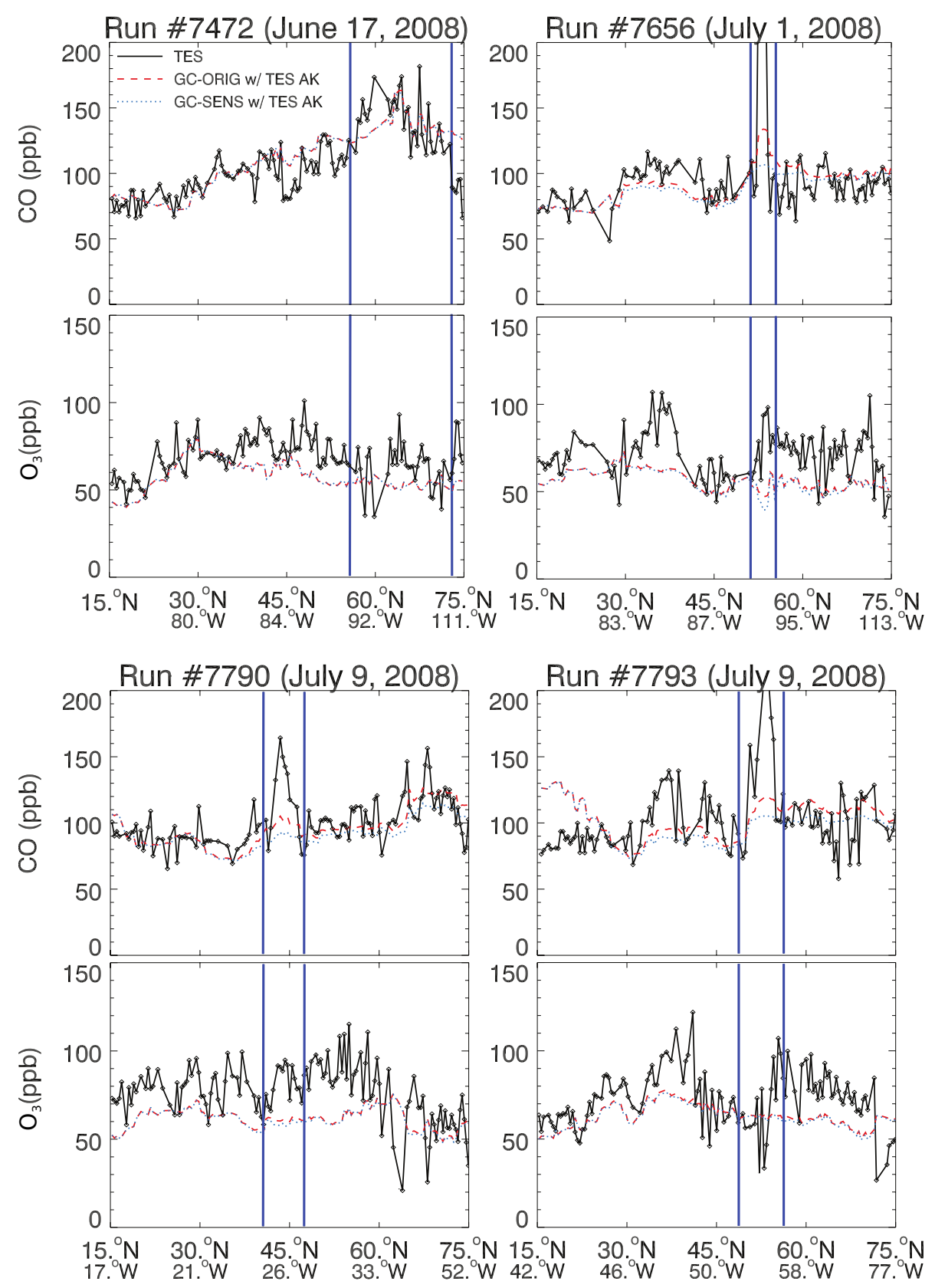

Fig. 12. CO and ozone mixing ratios at $510.9 \mathrm{hPa}$ for four TES runs influenced by biomass burning smoke from Canada. The solid black line is the TES retrieval, the red dashed line is the GC-ORIG model run results with the TES averaging kernel (AK) applied, and the dotted blue line is the GC-SENS model run results with the TES averaging kernel applied. The solid blue lines represent the approximate edges of the plume.

that the ARCTAS-B period had relatively low $\mathrm{NO}_{\mathrm{y}}$ emissions from fires, and the previous studies thus sampled plumes with higher ozone production. The $\mathrm{NO}_{\mathrm{y}}$ enhancements observed by Val Martin et al. (2006) (mean of $0.8 \%$, range of $0.42-2.2 \%$ ) are consistent with the DC8 observations for ARCTAS-B, suggesting that the initial $\mathrm{NO}_{\mathrm{x}}$ emissions of the sampled plumes were similar. However, there could have been a loss of $\mathrm{NO}_{\mathrm{y}}$ during the 6 to 15 days it took the plumes to travel to the Azores due to $\mathrm{HNO}_{3}$ formation and deposition, so the initial $\mathrm{NO}_{\mathrm{x}}$ emissions may have been higher than seen in ARCTAS-B. 

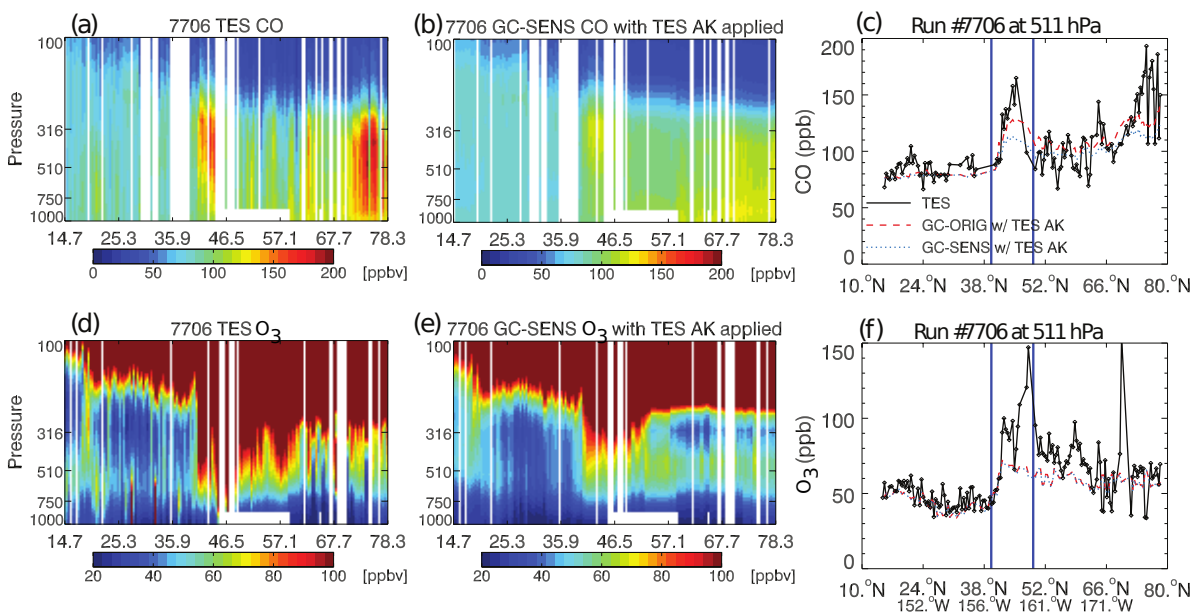

Fig. 13. Same as Figure 11 but for TES run 7706 on 3 July 2008.
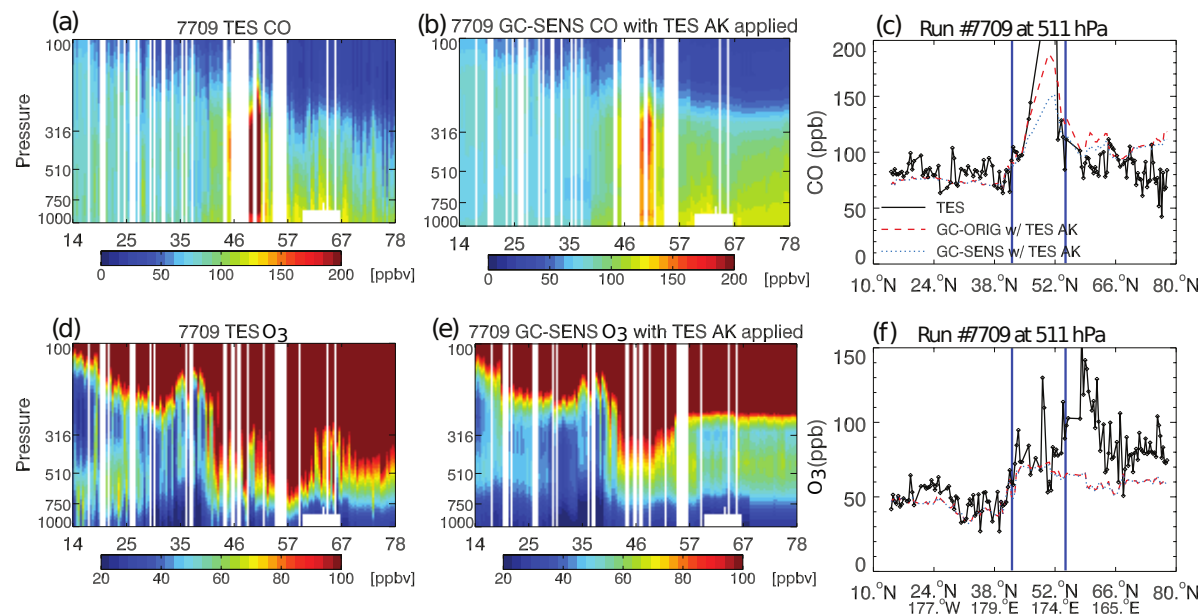

Fig. 14. Same as Figure 11 but for TES run 7709 on 4 July 2008.

\section{Conclusions}

We derived the enhancement ratios of $\mathrm{NO}_{\mathrm{y}}$ species from fresh Canadian biomass burning plumes sampled by the NASA DC8 during ARCTAS-B and explored the transformations of $\mathrm{NO}_{\mathrm{y}}$ as the plumes aged. We found that the mean $\mathrm{NO}_{\mathrm{y}}$ enhancement ratio in all the plumes was $0.7 \% \pm 0.5 \%$, which is consistent with the mean values of $0.8 \%$ and $0.56 \%$ from Val Martin et al. (2006) and Wofsy et al. (1992), respectively. Our mean molar emission ratio of $\mathrm{NO}_{\mathrm{x}}$ of $0.34 \% \pm 0.52 \%$ is well below the Nance et al. (1993) measurement of $1.2 \%$ for $\mathrm{NO}_{\mathrm{x}}$ and the Goode et al. (2000) measurement of $1.4-1.8 \%$ for NO. We derive an initial emission factor for $\mathrm{NO}_{\mathrm{x}}$ of $1.06 \mathrm{~g} \mathrm{NO} / \mathrm{kg} \mathrm{DM}$ which is much lower than the emission factor for $\mathrm{NO}_{\mathrm{x}}$ given in Andreae and Merlet (2001) for extratropical forest fires of $3.0 \mathrm{~g} \mathrm{NO} / \mathrm{kg} \mathrm{DM}$. In general, the exact emissions of $\mathrm{NO}_{\mathrm{x}}$ from boreal fires will depend on the fuel nitrogen content, the amount of flaming versus smoldering combustion, and other factors. Future research should develop better estimates of the mass fraction of nitrogen in the burned matter of forest fires based on geography and fire type, better quantify the amount of smoldering versus flaming combustion in wildfires, and develop parameterizations that connect these parameters to the emissions of $\mathrm{NO}_{\mathrm{x}}$.

The observations of the Lake McKay fire plume on 1 July showed for the first time that PAN is formed rapidly after emission, within $1-2 \mathrm{~h}$. On average, $40 \%$ of the initial $\mathrm{NO}_{\mathrm{x}}$ emissions were converted to PAN and $20 \%$ were converted to $\mathrm{NO}_{3(\mathrm{p})}$ shortly after emission. Our analysis shows that the enhancement ratio of $\mathrm{NO}_{\mathrm{x}}$ observed in a young smoke plume varies greatly depending on the age of the sampled smoke. 

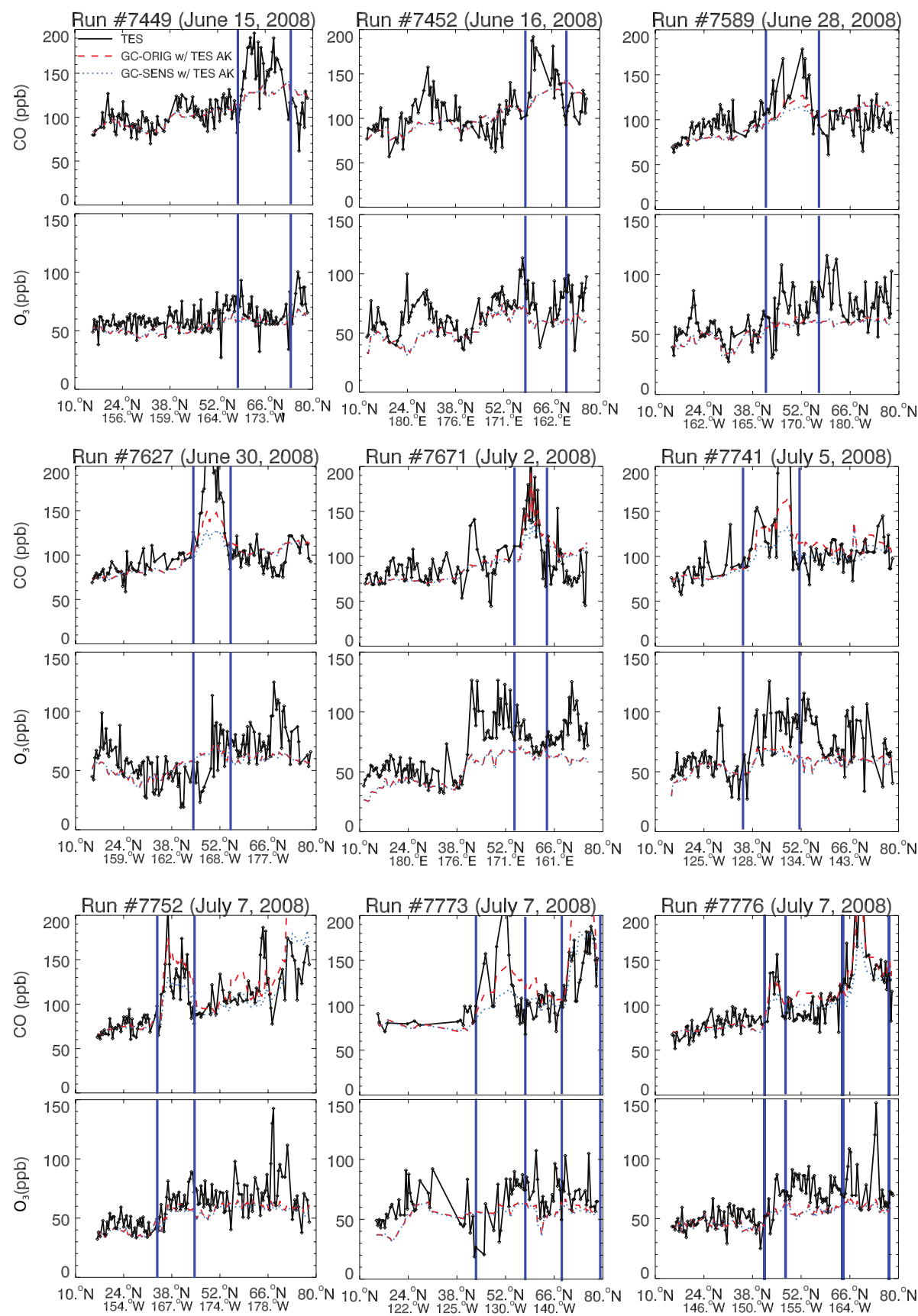

Fig. 15. Same as Figure 12 but for nine TES runs influenced by biomass burning smoke from Siberia.

We compared the results of three GEOS-Chem simulations with the NASA DC8 aircraft data and the TES special observations performed during ARCTAS-B. The original model run overestimated $\mathrm{CO}$ and $\mathrm{NO}_{\mathrm{y}}$ species relative to the aircraft observations below $3 \mathrm{~km}$. Reducing the FLAMBE estimate of biomass consumed in extratropical fires to $37.5 \%$ of the original value and incorporating pseudo-emission factors for $\mathrm{NO}_{\mathrm{x}}, \mathrm{PAN}$, and $\mathrm{HNO}_{3(\mathrm{~g})}$ to match the enhancement ratios observed in fresh biomass burning plumes improved the match between the model and the aircraft observations for $\mathrm{CO}$ and $\mathrm{NO}_{\mathrm{x}}$, but the model still had difficulty reproducing the observed vertical profiles of ozone, $\mathrm{HNO}_{3(\mathrm{~g})}$ and PAN. These remaining discrepancies could be due to the injection of biomass burning emissions above the boundary layer, stratospheric-tropospheric exchange of ozone near the plumes, and model underestimates of acetaldehyde emissions, all of which should be investigated in future work. The new emissions reduced the modeled concentrations of ozone 

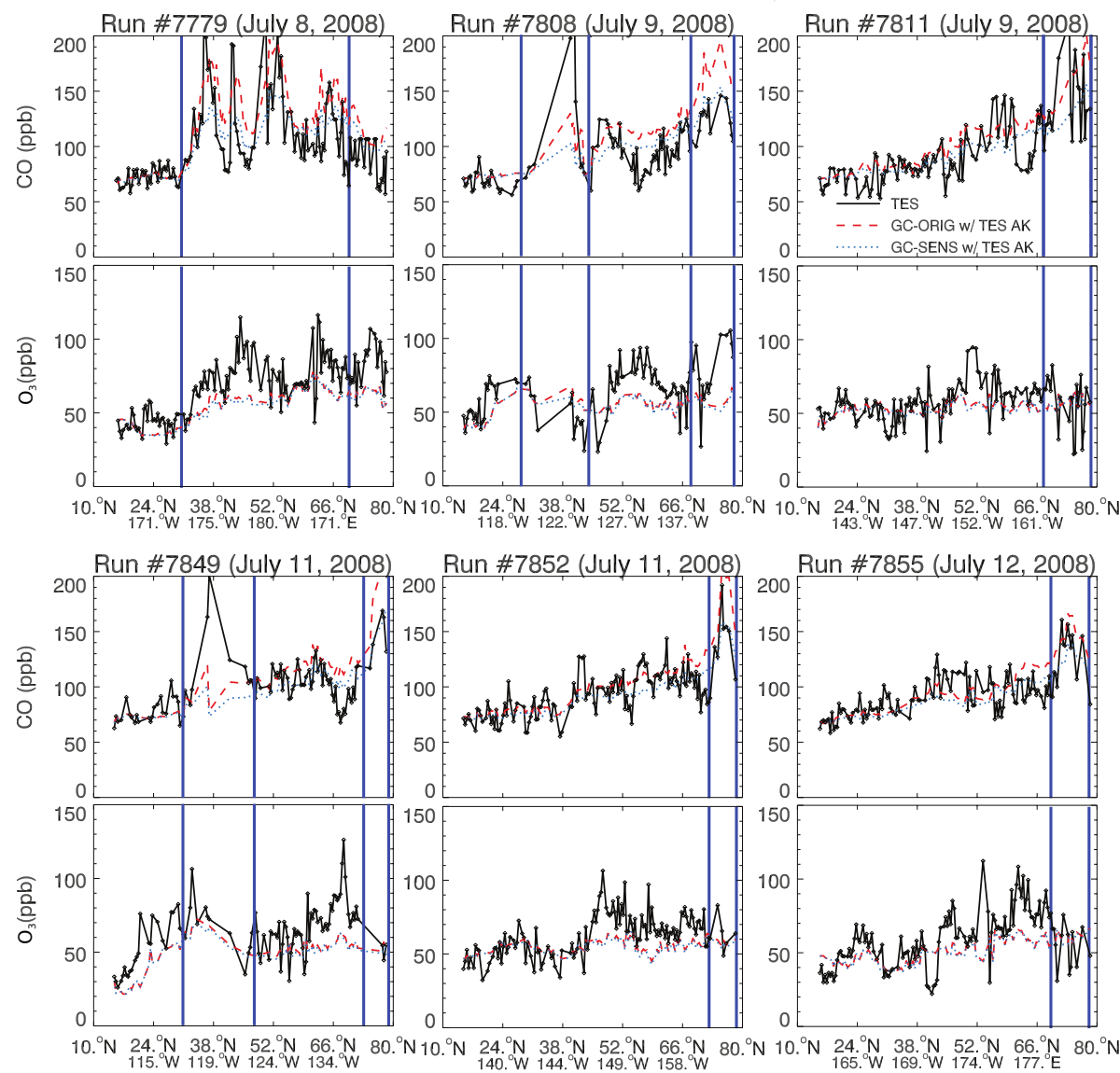

Fig. 16. Same as Figure 12 but for six TES runs influenced by biomass burning smoke from Siberia.

and $\mathrm{CO}$ within the boreal smoke plumes, and had similar, though smaller, effects throughout the Arctic.

We find little clear evidence for ozone formation in the boreal smoke plumes during ARCTAS-B in either the aircraft, satellite, or model results. Ozone was correlated with $\mathrm{CO}$ in only 9 of the 34 biomass burning plumes sampled by the NASA DC8 with an average enhancement ratio in fresh plumes of $+0.5 \% \pm 1.9 \%$, consistent with the work of Mauzerall et al. (1996) over Canada. Of the 22 biomass burning plumes observed by TES during ARCTAS-B, only 4 showed evidence of ozone increasing within the smoke plumes, and even in those cases it was unclear that the increase was caused by fire emissions, consistent with the study of Verma et al. (2009). In addition, the GEOS-Chem model results show that when the new $\mathrm{NO}_{\mathrm{y}}$ emissions estimates derived from the DC8 observations are used, the model shows no significant impacts of the fire emissions on Arctic ozone. This is in contrast to several previous studies showing ozone enhancements in boreal biomass burning plumes observed over the Azores (Honrath et al., 2004; Val Martin et al., 2006). These high ozone enhancement ratios may be the result of an increased photochemical production of ozone that occurs over the Azores when the biomass burning plumes are transported southward and descend, leading to the reconversion of PAN to $\mathrm{NO}_{\mathrm{x}}$ in the warmer mid-latitudes.

Acknowledgements. We thank all of the members of the ARCTAS Science Team and the TES Science Team for their work. We thank D. J. Jacob, J. A. Fisher, and Q. Wang of Harvard and the anonymous reviewers for their helpful comments. This research was supported by NASA grant NNX09AC51G to Harvard University (MJA and JAL) and NASA grant NBNX08AD39G to the University of Colorado (MJC and JLJ). PTR-MS measurements were supported by the Austrian Research Promotion Agency (FFG), the Tiroler Zukunftstiftung and the research groups led by A. Hansel and T. D. Märk.

Edited by: P. Monks 


\section{References}

Alvarado, M. J. and Prinn, R. G.: Formation of ozone and growth of aerosols in young smoke plumes from biomass burning, Part 1: Lagrangian parcel studies, J. Geophys. Res., 114, D09306, doi:10.1029/2008JD011144, 2009.

Andreae, M. O. and Merlet, P.: Emission of trace gases and aerosols from biomass burning, Global Biogeochem. Cy., 15, 955-966, 2001.

Apel, E., Hills, A., Lueb, R., Zindel, S., Eisele, S., and Riemer, D.: A fast-GC/MS system to measure C-2 to C-4 carbonyls and methanol aboard aircraft, J. Geophys. Res., 108, 8794, doi:10.1029/2002JD003199, 2003.

Atkinson, R., D., Baulch, L., Cox, R. A., Crowley, J. N., Hampson, R. F., Hynes, R. G., Jenkin, M. E., Rossi, M. J., and Troe, J.: Evaluated kinetic and photochemical data for atmospheric chemistry: Volume II - gas phase reactions of organic species, Atmos. Chem. Phys., 6, 3625-4055, doi:10.5194/acp-6-3625-2006, 2006.

Bertschi, I. T. and Jaffe, D. A.: Long-range transport of ozone, carbon monoxide, and aerosols to the NE Pacific troposphere during the summer of 2003: Observations of smoke plumes from Asian boreal fires, J. Geophys. Res., 110, D05303, doi:10.1029/2004JD005 135, 2005.

Bey, I., Jacob, D., Yantosca, R., Logan, J., Field, B., Fiore, A., li, Q., liu, H., Mickley, L., and Shultz, M.: Global modeling of Tropospheric chemistry with assimilated meteorology: Model description and evaluation, J. Geophys. Res., 106, 23073-23096, 2001.

Bian, H. S. and Prather, M. J.: Fast-J2: Accurate simulation of stratospheric photolysis in global chemical models, J. Atmos. Chem., 41, 281-296, doi:10.5194/acp-41-281-2002, 2002.

Blake, N. J., Blake, D. R., Simpson, I. J., Meinardi, S., Swanson, A. L., Lopez, J. P., Katzenstein, A. S., Barletta, B., Shirai, T., Atlas, E., Sachse, G., Avery, M., Vay, S., Fuelberg, H. E., Kiley, C. M., Kita, K., and Rowland, F. S.: NMHCs and halocarbons in Asian continental outflow during the Transport and Chemical Evolution over the Pacific (TRACE-P) Field Campaign: Comparison with PEM-West B, J. Geophys. Res., 108, 8806, doi:10.1029/2002JD003367, 2003.

Boxe, C. S., Worden, J. R., Bowman, K. W., Kulawik, S. S., Neu, J. L., Ford, W. C., Osterman, G. B., Herman, R. L., Eldering, A., Tarasick, D. W., Thompson, A. M., Doughty, D. C., Hoffmann, M. R., and Oltmans, S. J.: Validation of northern latitude tropospheric emission spectrometer stare ozone profiles with ARCIONS sondes during ARCTAS, Atmos. Chem. Phys. Discuss., 9, 27267-27301, doi:10.5194/acpd-9-27267-2009, 2009.

Cook, P. A., Savage, N. H., Turquety, S., Carver, G. D., O'Connor, F. M., Heckel, A., Stewart, D., Whalley, L. K., Parker, A. E., Schlager, H., Singh, H. B., Avery, M. A., Sachse, G. W., Brune, W., Richter, A., Burrows, J. P., Purvis, R., Lewis, A. C., Reeves, C. E., Monks, P. S., Levine, J. G., and Pyle, J. A.: Forest fire plumes over the North Atlantic: p-TOMCAT model simulations with aircraft and satellite measurements from the ITOP/ICARTT campaign, J. Geophys. Res., D10S43, doi:10.1029/2006JD007563, 2007.

Cooper, O., Forster, C., Parrish, D., Dunlea, E., Hubler, G., Fehsenfeld, F., Holloway, J., Oltmans, S., Johnson, B., Wimmers, A., and Horowitz, L.: On the life cycle of a stratospheric intrusion and its dispersion into polluted warm conveyor belts, J. Geophys.
Res., 109, D23S09, doi:10.1029/2003JD004 006, 2004.

Crounse, J., McKinney, K., Kwan, A., and Wennberg, P.: Measurement of gas-phase hydroperoxides by chemical ionization mass spectrometry (CIMS), Anal. Chem., 78, 6726-6732, 2006.

Crounse, J. D., DeCarlo, P. F., Blake, D. R., Emmons, L. K., Campos, T. L., Apel, E. C., Clarke, A. D., Weinheimer, A. J., McCabe, D. C., Yokelson, R. J., Jimenez, J. L., and Wennberg, P. O.: Biomass burning and urban air pollution over the Central Mexican Plateau, Atmos. Chem. Phys., 9, 4929-4944, doi:10.5194/acp-9-4929-2009, 2009.

Crounse, J. D., DeCarlo, P. F., Blake, D. R., Emmons, L. K., Campos, T. L., Apel, E. C., Clarke, A. D., Weinheimer, A. J., McCabe, D. C., Yokelson, R. J., Jimenez, J. L., and Wennberg, P. O.: Biomass burning and urban air pollution over the Central Mexican Plateau, Atmos. Chem. Phys., 9, 4929-4944, doi:10.5194/acp-9-4929-2009, 2009.

DeCarlo, P., Dunlea, E., Kimmel, J., Aiken, A., Sueper, D., Crounse, J., Wennberg, P., Emmons, L., Shinozuka, Y., Clarke, A., Zhou, J., Tomlinson, J., Collins, D., Knapp, D., Weinheimer, A., Campos, T., and Jimenez., J.: Fast airborne aerosol size and chemistry measurements above Mexico City and Central Mexico during the MILAGRO campaign, Atmos. Chem. Phys., 8, 40274048, doi:10.5194/acp-8-4027-2008, 2008.

Diskin, G., Podolske, J., Sachse, G. W., and Slate, T.: Open-path airborne tunable diode laser hygrometer, in: Diode lasers and applications in atmospheric sensing, edited by: Fried, A., SPIE Proc., 4817, 196-204, 2002.

Fisher, J. A., Jacob, D. J., Purdy, M. T., Kopacz, M., Sager, P. L., Carouge, C., Holmes, C. D., Yantosca, R. M., L.Batchelor, R., Strong, K., Diskin, G. S., Fuelberg, H. E., Holloway, J. S., Hyer, E. J., McMillan, W. W., Warner, J., Streets, D. G., Zhang, Q., Wang, Y., and Wu, S.: Source attribution and interannual variability of Arctic pollution in spring constrained by aircraft (ARCTAS, ARCPAC) and satellite (AIRS) observations of carbon monoxide, Atmos. Chem. Phys., 10, 977-996, doi:10.5194/acp10-977-2010, 2010.

Fuelberg, H., Harrigan, D., and Sessions, W.: A meteorological overview of the ARCTAS 2008 mission, Atmos. Chem. Phys., 10, 817-842, doi:10.5194/acp-10-817-2010, 2010.

Giglio, L.: Characterization of the tropical diurnal fire cycle using VIRS and MODIS observations, Remote Sens. Environ., 108, 407-421, 2007.

Giglio, L., van der Werf, G. R., Randerson, J. T., Collatz, G. J., , and Kasibhatla, P.: Global estimation of burned area using MODIS active fire observations, Atmos. Chem. Phys., 6, 957974, doi:10.5194/acp-6-957-2006, 2006.

Goode, J. G., Yokelson, R. J., Ward, D. E., Susott, R. A., Babbitt, R. E., Davies, M. A., and Hao, W. M.: Measurements of Excess O3, CO2, CO, CH4, C2H4, C2H2, HCN, NO, NH3, $\mathrm{HCOOH}, \mathrm{CH} 3 \mathrm{COOH}, \mathrm{HCHO}$ and $\mathrm{CH} 3 \mathrm{OH}$ in 1997 Alaskan Biomass Burning Plumes by Airborne Fourier Transform Infrared Spectroscopy (AFTIR), J. Geophys. Res., 105, 2214722166, 2000.

Herman, J. R. and Celarier, E. A.: Earth surface reflectivity climatology at 340-380 nm from TOMS data, J. Geophys. Res., 102, 28003-28011, 1997.

Honrath, R. E., Owen, R. C., Val Martin, M., Reid, J., Lapina, K., Fialho, P., Dziobak, M. P., Kleissl, J., and Westphal, D. L.: Regional and hemispheric impacts of anthropogenic and biomass 
burning emissions on summertime $\mathrm{CO}$ and $\mathrm{O}_{3}$ in the North Atlantic lower free troposphere, J. Geophys. Res., 109, D24310, doi:10.1029/2004JD005147, 2004.

Hudman, R. C., Jacob, D. J., Turquety, S., Leibensperger, E. M., Murray, L. T., Wu, S., Gilliland, A., Avery, M., Bertram, T., Brune, W., Cohen, R., Dibb, J., Flocke, F., Firied, A., Holloway, J., Neuman, J., Orville, R., Perring, A., Ren, X., Sachse, G., Singh, H., Swanson, A., and Wooldridge, P.: Surface and lightning sources of nitrogen oxides over the United States: Magnitudes, chemical evolution, and outflow., J. Geophys. Res., 112, D12S05, doi:10.1029/2006JD007912, 2007.

Ichoku, C., Giglio, L., Wooster, M. J., and Remer, L. A.: Global characterization of biomass-burning patterns using satellite measurements of fire radiative energy, Remote Sens. Environ., 112, 2950-2962, 2008.

Isobe, T., Feigelson, E. D., Akritas, M. G., and Babu, G. J.: Linear regression in astronomy., Astrophys. J., Part 1, 364, 104-113, 1990.

Jacob, D., Wofsy, S., Bakwin, P., Fan, S.-M., Harriss, R., Talbot, R., Bradshaw, J., Sandholm, S., Singh, H., Browell, E.V. Gregory, G., Sachse, G., Shipham, M., Blake, D., and Fitzjarrald, D.: Summertime Photochemistry of the Troposphere at High Northern Latitudes, J. Geophys. Res., 97(15), doi:10.1029/91JD01968, 16421-16431, 1992.

Jacob, D. J., Crawford, J. H., Maring, H., Clarke, A. D., Dibb, J. E., Emmons, L. K., Ferrare, R. A., Hostetler, C. A., Russell, P. B., Singh, H. B., Thompson, A. M., Shaw, G. E., McCauley, E., Pederson, J. R., and Fisher, J. A.: The Arctic Research of the Composition of the Troposphere from Aircraft and Satellites (ARCTAS) mission: design, execution, and first results, Atmos. Chem. Phys., 10, 5191-5212, doi:10.5194/acp-10-5191-2010, 2010.

Kim, S., Huey, L., Stickel, R., Tanner, D., Crawford, J., Olson, J., Chen, G., Brune, W., Ren, X., Lesher, R., Wooldridge, P., Bertram, T., Perring, A., Cohen, R., Lefer, B., Shetter, R., Avery, M., Diskin, G., and Sokolik, I.: Measurement of pernitric acid in the free troposphere during the intercontinental chemical transport experiment - North America, J. Geophys. Res., 112, D12S01, doi:10.1029/2006JD007676, 2007.

Leung, F.-Y. T., Logan, J. A., Park, R., Hyer, E., Kaisischke, E., Streets, D., and Yurganov, L.: Impacts of enhanced biomass burning in the boreal forests in 1998 on tropospheric chemistry and the sensitivity of model results to the injection height of emissions, J. Geophys. Res., 112, D10313, doi:10.1029/2006JD008132, 2007.

Lobert, J. M., Scharffe, D. S., Hao, W. M., and Crutzen, P. J.: Importance of biomass burning in the atmospheric budgets of nitrogencontaining gases, Nature, 346, 552-554, 1990.

Mao, J., Jacob, D. J., Evans, M. J., Olson, J. R., Ren, X., Brune, W. H., Clair, J. M. St., Crounse, J. D., Spencer, K. M., Beaver, M. R., Wennberg, P. O., Cubison, M. J., Jimenez, J. L., Fried, A., Weibring, P., Walega, J. G., Hall, S. R., Weinheimer, A. J., Cohen, R. C., Chen, G., Crawford, J. H., McNaughton, C., Clarke, A. D., Jaegl, L., Fisher, J. A., Yantosca, R. M., Le Sager, P., and Carouge, C.: Chemistry of hydrogen oxide radicals $\left(\mathrm{HO}_{\mathrm{x}}\right)$ in the Arctic troposphere in spring, Atmos. Chem. Phys., 10, 58235838, doi:10.5194/acp-10-5823-2010, 2010.

Mauzerall, D., Jacob, D. J., Fan, S.-M., Bradshaw, J., Gregory, G., Sachse, G., and Blake, D.: Origin of tropospheric ozone at remote high northern latitudes in summer, J. Geophys. Res., 101,
4175-4188, 1996

Mauzerall, D. L., Logan, J. A., Jacob, D. J., Anderson, B. E., Blake, D. R., Bradshaw, J. D., Heikes, B., Sachse, G. W., Singh, H., and Talbot, B.: Photochemistry in biomass burning plumes and implications for tropospheric ozone over the tropical South Atlantic, J. Geophys. Res., 103, 8401-8423, 1998.

McKeen, S., Wotawa, G., Parrish, D., Holloway, J., Buhr, M., Hubler, G., Fehsenfeld, F., and Meagher, J.: Ozone production from Canadian wildfires during June and July of 1995, J. Geophys. Res., 107(D14), 4192, doi:10.1029/2001JD000697, 2002.

Nance, J. D., Hobbs, P. V., and Radke, L. F.: Airborne measurements of gases and particles from an Alaskan wildfire, J. Geophys. Res., 98, 14873-14882, 1993.

Nowak, J., Parrish, D., Neuman, J., Holloway, J., Cooper, O., Ryerson, T., Jr., D. K. N., Flocke, F., Roberts, J., Atlas, E., de Gouw, J. A., Donnelly, S., Dunlea, E., Hubler, G., Huey, L., Schauffler, S., Tanner, D., Warneke, C., and Fehsenfeld, F. C.: Gas-phase chemical characteristics of Asian emission plumes observed during ITCT 2K2 over the eastern North Pacific Ocean, J. Geophys. Res., 109, D23S19, doi:10.1029/2003JD004488, 2004.

Osterman, G., Bowman, K .and Eldering, A., Fisher, B., Herman, R., Jacob, D., Jourdain, L., Kulawik, S., Luo, M., Monarrez, R., Paradise, S., Poosti, S., Richards, N., Rider, D., Shepard, D., Vilnrotter, F., Worden, H., Worden, J., and Yun, H.: Earth Observating System (EOS) Tropospheric Emission Spectrometer (TES) Level 2 (L2) data user's guide, Tech. rep., Jet Propulsion Laboratory, California Institute of technology, Pasadena, California, USA, 2008.

Park, R. J., Jacob, D. J., Kumar, N., and Yantosca, R. M.: Regional visibility statistics in the United States: Natural and transboundary pollution influences, and implications for the Regional Haze Rule, Atmos. Environ., 40, 5405-5423, 2006.

Pfister, G., Emmons, L. K., Hess, P. G., Honrath, R., Lamarque, J.F., Val Martin, M., Owen, R. C., Avery, M., Browell, E. V., Holloway, J. S., Nedelec, P., Purvis, R., Rywerson, T. B., Sachse, G. W., and Schlager, H.: Ozone production from the 2004 North American boreal fires, J. Geophys. Res., 111, D24S07, doi:10.1029/2006JD007 695, 2006.

Real, E., Law, K., Weinzierl, B., Fiebig, M., Petzold, A., Wild, O., Methven, J., Arnold, S., Stohl, A., Huntrieser, H., Roiger, A., Schlager, H., D., S., Avery, M., Sachse, G., Browell, E., Ferrare, R., and Blake, D.: Processes influencing ozone levels in Alaskan forest fire plumes during long-range transport over the North Atlantic, J. Geophys. Res., D10S41, doi:10.1029/2006JD007576, 2007.

Reid, J., Hyer, E., Prins, E., Westphal, D. L., Zhang, J., Wang, J., Christopher, S., Curtis, C., Schmidt, C., Eleuterio, D., Richardsonb, K., and Hoffman, J.: Global monitoring and forecasting of biomass-burning smoke: Description of and lessons from the Fire Locating and Modeling of Burning Emissions (FLAMBE) program, IEEE J. Appl. Earth Observ. Remote Sens., 2, 144 161, 2009.

Rienecker, M., Suarez, M., Todling, R., Bacmeister, J., Takacs, L., Liu, H., Gu, W., Sienkiewicz, M., Koster, R., Gelaro, R., Stajner, I., and Nielsen, E.: The GEOS-5 Data Assimilation System - Documentation of Versions 5.0.1, 5.1.0, and 5.2.0, Tech. rep., NASA/TM-2007-104606, vol. 27, edited by: Suarez, M. J., 2007.

Sachse, G., Hill, G., Wade, L., and Perry, M.: Fast-response, high- 
precision carbon monoxide sensor using a tunable diode laser absorption technique, J. Geophys. Res., 92, 2071-2081, 1987.

Sander, S. P., Friedl, R. R., Ravishankara, A. R., Golden, D. M., and Kurylo., M. J.: Chemical kinetics and photochemical data for use in atmospheric studies evaluation number 15., Jet Propulsion Laboratory, NASA, 2006.

Sinha, P., Hobbs, P. V., Yokelson, R. J., Bertschi, I. T., Blake, D. R., Simpson, I. J., Gao, S., Kirchstetter, T. W., and Novakov, T.: Emissions of Trace Gases and Particles from Savanna Fires in Southern Africa, J. Geophys. Res., 108, 8487, doi:10.1029/2002JD002325, 2003.

Slusher, D., Huey, L. G., Tanner, D. J., Flocke, F. M., , and Roberts, J. M.: A thermal dissociation chemical ionization mass spectrometry (TD-CIMS) technique for the simultaneous measurement of peroxyacyl nitrates and dinitrogen pentoxide, J. Geophys. Res., 109, D19315, doi:10.1029/2004JD004670, 2004.

Soja, A. J., Stocks, B., Maczek, P., Fromm, M., Servranckx, R., Turetsky, M., and Benscoter, B.: ARCTAS: The Perfect Smoke, The Canadian Smoke Newsletter, Fall, 2-7, 2008.

Turquety, S., Logan, J. A., Jacob, D. J., Hudman, R. C., Leung, F.-Y., Heald, C. L., Yantosca, R. C., Wu, S., Emmons, L. K., Edwards, D. P., and Sachse, G. W.: Inventory of boreal fire emissions for North America in 2004: Importance of peat burning and pyroconvective injection, J. Geophys. Res., 112, D12S03, doi:10.1029/2006JD007281, 2007.

Val Martin, M., Honrath, R., Owen, R., Pfister, G., Fialho, P., and Barata, F.: Significant enhancements of nitrogen oxides, black carbon, and ozone in the North Atlantic lower free troposphere resulting from North American boreal wildfires, J. Geophys. Res., D23S60, doi:10.1029/2006JD007530, 2006.

Val Martin, M., Logan, J. A., Kahn, R., Leung, F.-Y., Nelson, D., and Diner, D.: Smoke injection heights from fires in North America: Analysis of five years of satellite observations, Atmos. Chem. Phys., 10, 1491-1510, doi:10.5194/acp-10-1491-2010, 2010.

van der Werf, G. R., Randerson, J. T., Giglio, L., Collatz, G. J., Kasibhatla, P. S., and Arellano Jr., A. F.: Interannual variability in global biomass burning emissions from 1997 to 2004, Atmos. Chem. Phys., 6, 3423-3441, doi:10.5194/acp-6-3423-2006, 2006.

van Donkelaar, A., Martin, R. V., Leaitch, W. R., Macdonald, A. M., Walker, T. W., Streets, D. G., Zhang, Q., Dunlea, E. J., Jimenez, J. L., Dibb, J. E., Huey, L. G., Weber, R., and Andreae, M. O.: Analysis of aircraft and satellite measurements from the Intercontinental Chemical Transport Experiment (INTEX-B) to quantify long-range transport of East Asian sulfur to Canada, Atmos. Chem. Phys., 8, 2999-3014, doi:10.5194/acp-8-2999-2008, 2008.

Vay, S. A., Woo, J. H., Anderson, B. E., Thornhill, K. L., Blake, D. R., Westberg, D. J., Kiley, C. M., Avery, M. A., Sachse, G. W., Streets, D., Tsutsumi, Y., and Nolf, S.: The influence of regional-scale anthropogenic emissions on $\mathrm{CO} 2$ distributions over the western North Pacific, J. Geophys. Res., 108, 8801, doi:10.1029/2002JD003094, 2003.
Verma, S., Worden, J., Pierce, B., Jones, D. B. A., Al-Saadi, J., Boersma, F., Bowman, K., Eldering, A., Fisher, B., Jourdain, L., Kulawik, S., and Worden, H.: Ozone production in boreal fire smoke plumes using observations from the Tropospheric Emission Spectrometer and the Ozone Monitoring Instrument, J. Geophys. Res., D02303, doi:10.1029/2008JD010108, 2009.

Weinheimer, A., Walega, J., Ridley, B., Gary, B., Blake, D., Blake, N., Rowland, F., Sachse, G., Anderson, B., and Collins, J.: Meridional distributions of NOx, NOy, and other species in the lower stratosphere and upper troposphere during AASE II, Geophys. Res. Lett., 21, 2583-2586, 1994.

Wild, O., Zhu, X., and Prather, M. J.: Fast-j: Accurate simulation of in- and below-cloud photolysis in tropospheric chemical models, J. Atmos. Chem., 37, 245-282, 2000.

Wisthaler, A., Hansel, A., Dickerson, R. R., and Crutzen, P. J.: Organic trace gas measurements by PTR-MS during INDOEX 1999, J. Geophys. Res., 107, 8024, doi:10.1029/2001JD000576, 2002.

Wofsy, S. C., Sachse, G., Gregory, G., Blake, D., Bradshaw, J., Sandholm, S., singh, H., Barrick, J., Harriss, R., Talbot, R., Shipham, M., Browell, E., Jacob, D. J., and Logan, J. A.: Atmospheric Chemistry in the Arctic and Subarctic: Influence of natural fires, industrial emissions, and stratospheric inputs, J. Geophys. Res., 97, 16731-16746, 1992.

Wotawa, G. and Trainer, M.: The influence of Canadian forest fires on pollutant concentrations in the United States, Science, 288, 324, doi:10.1126/science.288.5464.324, 2000.

Yokelson, R. J., Griffith, D. W., and Ward, D. E.: Open-Path Fourier Transform Infrared Studies of Large-Scale Laboratory Biomass Fires, J. Geophys. Res., 101, 21067-21080, 1996.

Zhang, L., Jacob, D. J., Bowman, K. W., Logan, J. A., Turquety, S., Hudman, R. C., Li, Q., Beer, R., Worden, H. M., Worden, J. R., Rinsland, C. P., Kulawik, S. S., Lampel, M. C., Shephard, M. W., Fisher, B. M., Eldering, A., and Avery, M. A.: Ozone$\mathrm{CO}$ correlations determined by the TES satellite instrument in continental outflow regions, Geophys. Res. Lett., 33, L18804, doi:10.1029/2006GL026399, 2006.

Zhang, L., Jacob, D. J., Boersma, K. F., Jaffe, D. A., Olson, J. R., Bowman, K. W., Worden, J. R., Thompson, A. M., Avery, M. A., Cohen, R. C., Dibb, J. E., Flocke, F. M., Fuelberg, H. E., Huey, L. G., McMillan, W. W., Singh, H. B., and Weinheimer, A. J.: Transpacific transport of ozone pollution and the effect of recent Asian emission increases on air quality in North America: an integrated analysis using satellite, aircraft, ozonesonde, and surface observations, Atmos. Chem. Phys., 8, 6117-6136, doi:10.5194/acp-8-6117-2008, 2008. 